\title{
Review on Toxic Effects of Di(2-ethylhexyl) Phthalate on Zebrafish Embryos
}

\author{
Wing Sum Kwan ${ }^{1,2}$, Vellaisamy A. L. Roy ${ }^{3, *}$ and Kwan Ngok Yu 1,4,* \\ 1 Department of Physics, City University of Hong Kong, Tat Chee Ave., Kowloon Tong, Kowloon, \\ Hong Kong, China; wingskwan8@cityu.edu.hk \\ 2 Department of Materials Science and Engineering, City University of Hong Kong, Tat Chee Ave., \\ Kowloon Tong, Kowloon, Hong Kong, China \\ 3 James Watt School of Engineering, University of Glasgow, Glasgow G12 8QQ, UK \\ 4 State Key Laboratory in Marine Pollution, City University of Hong Kong, Tat Chee Ave., Kowloon Tong, \\ Kowloon, Hong Kong, China \\ * Correspondence: roy.vellaisamy@glasgow.ac.uk (V.A.L.R.); peter.yu@cityu.edu.hk (K.N.Y.)
}

check for

updates

Citation: Kwan, W.S.; Roy, V.A.L.; Yu, K.N. Review on Toxic Effects of Di(2-ethylhexyl) Phthalate on

Zebrafish Embryos. Toxics 2021, 9, 193. https://doi.org/10.3390/toxics9080193

Academic Editor: Ki-Tae Kim

Received: 10 June 2021

Accepted: 14 August 2021

Published: 21 August 2021

Publisher's Note: MDPI stays neutral with regard to jurisdictional claims in published maps and institutional affiliations.

Copyright: (c) 2021 by the authors. Licensee MDPI, Basel, Switzerland. This article is an open access article distributed under the terms and conditions of the Creative Commons Attribution (CC BY) license (https:/ / creativecommons.org/licenses/by/ $4.0 /)$.

\begin{abstract}
Di(2-ethylhexyl) phthalate (DEHP) is widely used as a plasticizer in consumer products People are continuously exposed to DEHP through ingestion, inhalation and dermal absorption. From epidemiological studies, DEHP has been shown to associate with various adverse health effects, such as reproductive abnormalities and metabolic diseases. Health concerns have been raised regarding DEHP exposures; therefore, relevant risk assessment has become necessary through toxicological testing of DEHP. In the past 10 years, an increasing number of DEHP toxicity studies have been using zebrafish embryos as an in vivo model due to their high fecundity, rapid embryonic development as well as optical transparency, which have now been established as an alternative of the more conventional rodent model. The aim of the present paper is to review the effects of acute (from embryo stage to $\leq 1$ week) and chronic (from embryo stage to $>1$ week) DEHP exposures on zebrafish, which start from the embryonic stage, and to analyze acute and potential long-term effects induced by acute exposure and effects induced by chronic exposure of DEHP upon subjecting to exposures, starting from the embryonic stage to different developmental stages, with a view to facilitate risk assessments on DEHP exposures.
\end{abstract}

Keywords: phthalate; di(2-ethylhexyl) phthalate (DEHP); mono-2-ethylhexyl phthalate (MEHP); zebrafish embryo; toxic effect

\section{Introduction}

Phthalates have been widely applied as plasticizers to enhance the flexibility of plastic in consumer products, such as toys, food containers, cosmetics, personal care products and furniture as well as medical devices [1], but at the same time have been recognized as endocrine disrupting chemicals (EDCs) [2]. Nowadays, people are pervasively exposed to phthalates through ingestion, inhalation and dermal absorption [1] since phthalates can easily migrate into the environment with time and use as they are not covalently bound to plastics [3-5].

Ten widely used phthalates were summarized by Wang et al., including dimethyl phthalate (DMP), diethyl phthalate (DEP), dibutyl phthalate (DBP), diisobutyl phthalate (DIBP), butyl benzyl phthalate (BBzP), dicyclohexyl phthalate (DCHP), di(2-ethylhexyl) phthalate (DEHP), di-n-octyl phthalate (DnOP), diisononyl phthalate (DINP) and diisodecyl phthalate (DIDP), the structures of which are depicted in Figure 1 [6]. 
<smiles>COC(=O)c1ccccc1C(=O)OC</smiles>

Dimethyl phthalate (DMP)<smiles>CCOC(=O)c1ccccc1C(=O)OCC</smiles>

Diethyl phthalate (DEP)<smiles>CCCCOC(=O)c1ccccc1C(=O)OCCCC</smiles>

Dibutyl phthalate (DBP)<smiles>CC(C)COC(=O)c1ccccc1C(=O)OCC(C)C</smiles>
(DIBP)

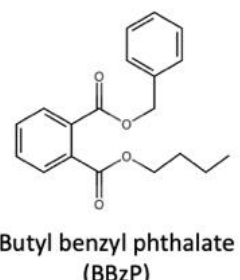

(BBzP)

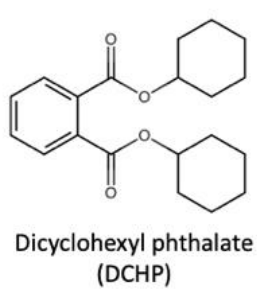
(DCHP)

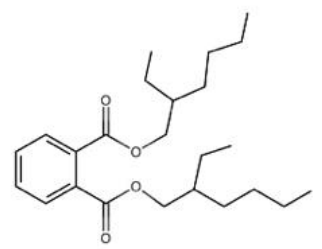

Di (2-ethylhexyl) phthalate (DEHP)

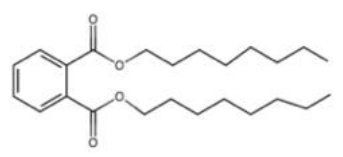

Di-n-octyl phthalate (DnOP)

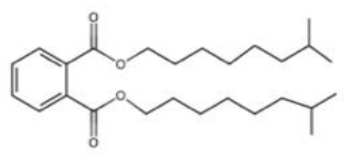

Diisononyl phthalate (DINP)

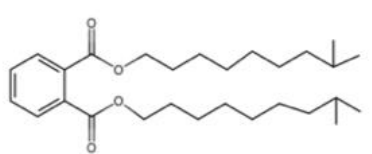

Diisodecyl phthalate (DIDP)

Figure 1. Ten widely used phthalates as summarized by Wang et al. [6].

In general, phthalates can be categorized as lower molecular weight (LMW) phthalates (e.g., DMP, DEP, BBzP) and higher molecular weight (HMW) phthalates (e.g., DEHP, DINP, DIDP) [7]. LMW-phthalates are used in paints, solvents, adhesives and body-care products, while HMW-phthalates are widely used as plasticizers. Notably, DEHP, which is the most extensively used phthalate accounting for nearly $50 \%$ of global phthalate consumption, has been associated with various adverse health effects [8]. In particular, DEHP has been classified as possibly carcinogenic to humans (Group 2B) by the International Agency for Research on Cancer Working Group [9] and also classified as priority environmental pollutants according to the United States Environmental Protection Agency (EPA) [10]. Furthermore, DEHP is restricted in children's toys in the European Union [11], the United States [12] and Canada [13].

In relation, mono-2-ethylhexyl phthalate (MEHP), the major metabolite of DEHP, was used as a biomarker of DEHP exposure, thanks to the metabolic pathway from DEHP to MEHP as shown in Figure 2 [6]. MEHP was detected in human urine, breast milk, blood and serum [14-16]. Besides, DEHP has been associated with various adverse health effects, such as reproductive abnormalities, metabolic diseases as well as allergy and asthma from epidemiological studies [17-22]. Zarenan et al. reviewed adverse health effects induced by DEHP in terms of effects on reproductive system, pregnancy outcome and respiratory health, as well as carcinogenesis in several in vitro, in vivo and epidemiological studies [8]. Furthermore, prenatal and perinatal DEHP exposures have been linked with restricted growth, delayed lung maturation, neuronal, behavioral and reproductive toxicity as well as obesity in rats [23-27]. Notably, in the past 10 years, an increasing number of DEHP developmental toxicity studies were carried out using zebrafish (Danio rerio) embryos as an in vivo model, which was considered an alternative to the conventional rodent model.<smiles>CCCCCCCCCCCCCCCCCCCCC(=O)OCC(CC)CCCC</smiles>

Di(2-ethylhexyl) phthalate (DEHP)
Primary Metabolite<smiles>CCCCC(CC)COC(=O)c1ccccc1C(=O)O</smiles>

Mono-2-ethylhexyl phthalate (MEHP)

Figure 2. Metabolic pathway from DEHP to MEHP [6]. 
Zebrafish has become a popular vertebrate model widely applied in toxicological studies due to its high fecundity, rapid embryonic development as well as optical transparency $[28,29]$. Moreover, development of zebrafish and mammals are similar. Importantly, the genomes of zebrafish and human share approximately $70 \%$ homology, which has made zebrafish a desirable model for studying human diseases [30]. Segner reviewed the studies which employed the zebrafish model to evaluate endocrine disrupting effects of different EDCs, such as Bisphenol A (BPA), ethynylestradiol (EE2) and phytosterols [31]. Besides, researchers adopted zebrafish embryos for studying developmental toxic effects of EDC exposures [32-34].

In the present review, a literature search was performed through Google Scholar (https: / / scholar.google.com/, accessed on 26 January 2021 (DEHP) and 17 March 2021 (MEHP)) with the keywords "DEHP AND zebrafish embryo" and "DEHP AND zebrafish larvae" for DEHP exposures as well as the keywords "MEHP AND zebrafish embryo" and "MEHP AND zebrafish larvae" for MEHP exposures. In particular, this review only included effects of DEHP or MEHP exposures on zebrafish, which started from the embryonic stage. In other words, studies that started to treat zebrafish with DEHP or MEHP at later developmental stages (i.e., larval, juvenile and adult stages) were excluded. Moreover, in the present review, the term "acute exposure" referred to exposures which started from the embryo stage to 1 week, while the term "chronic exposure" referred to exposures which started from the embryo stage and assessment of the zebrafish at an age more than 1 week. We summarized the effects of acute and chronic DEHP exposures on zebrafish, which started from the embryonic stage, and analyzed acute and potential long-term effects induced by acute exposures, and effects induced by chronic exposures of DEHP through various biological endpoints at different developmental stages of the zebrafish, in order to facilitate risk assessment on DEHP, as outlined in Figure 3.

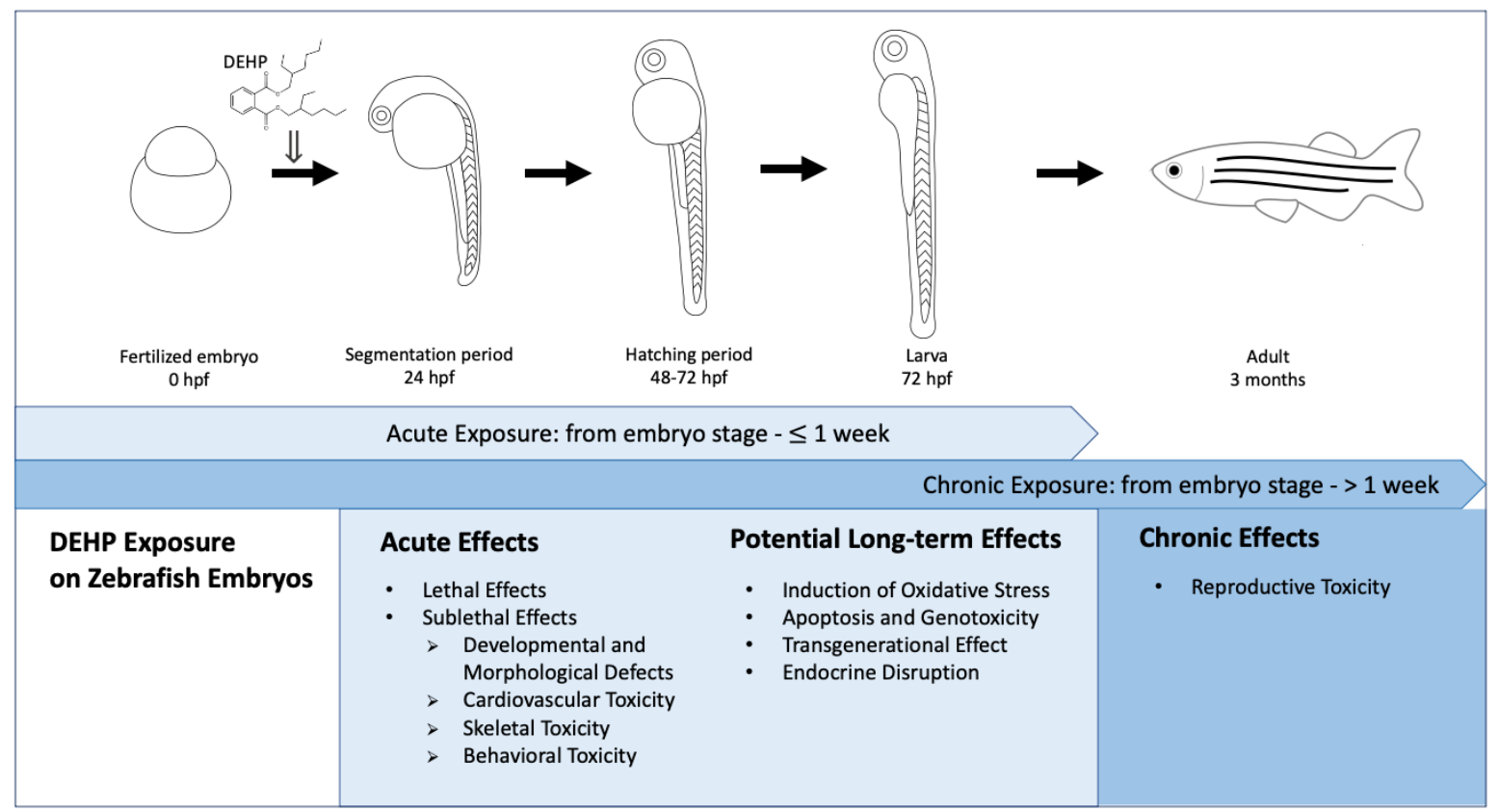

Figure 3. Effects of acute (from embryo stage to $\leq 1$ week) and chronic (from embryo stage to $>1$ week) DEHP exposures on zebrafish, which started from the embryonic stage to different developmental stages of the zebrafish [35]. (hpf: hours post-fertilization).

\section{Acute Effects Induced by Acute Exposure}

\subsection{Lethal Effects}

Standardized endpoints have been established for evaluating the mortality of zebrafish embryos in toxicity tests. Lethal endpoints included coagulation of eggs or embryos, nondetachment of tail, somite development failure as well as lack of heartbeat [36]. Increased 
mortality rate was reported in DEHP-exposed zebrafish embryos [37-39]. In particular, Muhammad et al. found a mortality rate of $37.6 \%$ for zebrafish embryos at $72 \mathrm{~h}$ postfertilization (hpf) upon exposures to $0.5 \mu \mathrm{g} / \mathrm{L}$ DEHP [39]. Two separate studies made use of the mortality rate at $168 \mathrm{hpf}$ as the endpoint in order to compare the toxic effects on zebrafish embryos among 6 types of phthalates, including DEP, DBP, DMP, BBzP, DnOP and DEHP $[37,38]$. When exposed to $50 \mu \mathrm{g} / \mathrm{L}$ phthalate, the highest mortality rate $(19.5 \%)$ was found in DEHP-treated embryos among all phthalate-treated embryos [38]. However, when a higher phthalate concentration $(10 \mathrm{mg} / \mathrm{L})$ was used, the mortality rate of DEHP ranked 5th among those tested phthalates [37]. The lethal concentration that caused 50\% mortality (LC50) of DEHP on zebrafish embryos was determined to be $2.5 \mu \mathrm{g} / \mathrm{L}$ in zebrafish embryos at $72 \mathrm{hpf}$ [40]. An independent study reported the LC50 value of DEHP for zebrafish embryos from 72 to $168 \mathrm{hpf}$ as $54.02 \mathrm{mg} / \mathrm{L}$ [41]. Regarding MEHP exposures, a significant increase in the mortality rate was observed in MEHP-exposed embryos in a dose- and time-dependent manner [42]. Table 1 summarizes the lethal effects from acute exposures to DEHP or MEHP on zebrafish embryos.

Table 1. Lethal effects from acute exposures to (a) DEHP and (b) MEHP on zebrafish embryos. ${ }^{* *}$ The concentration was converted from $\mathrm{nM}$ or $\mu \mathrm{M}$ using the molar mass of MEHP $278.34 \mathrm{~g} / \mathrm{mol}$.

\begin{tabular}{|c|c|c|c|c|}
\hline \multicolumn{5}{|l|}{ (a) DEHP } \\
\hline Endpoint & Lowest Effective Dose & Exposure & Endpoint Time & References \\
\hline \multirow[t]{3}{*}{ mortality rate increased } & $0.5 \mu \mathrm{g} / \mathrm{L}$ & $27-72 \mathrm{hpf}$ & $72 \mathrm{hpf}$ & [39] \\
\hline & $25 \mu \mathrm{g} / \mathrm{L}$ & 3-168 hpf & $168 \mathrm{hpf}$ & {$[38]$} \\
\hline & $200 \mathrm{mg} / \mathrm{L}$ & $1-168 \mathrm{hpf}$ & $168 \mathrm{hpf}$ & [37] \\
\hline \multirow[t]{2}{*}{ survival (LC50) } & $2.5 \mu \mathrm{g} / \mathrm{L}$ & start at embryo stage $-72 \mathrm{hpf}$ & $72 \mathrm{hpf}$ & {$[40]$} \\
\hline & $54.02 \mathrm{mg} / \mathrm{L}$ & $72-168 \mathrm{hpf}$ & $72-168 \mathrm{hpf}$ & {$[41]$} \\
\hline \multicolumn{5}{|l|}{ (b) MEHP } \\
\hline Endpoint & Lowest Effective Dose & Exposure & Endpoint Time & References \\
\hline mortality rate increased & $* * 2.8 \mathrm{mg} / \mathrm{L}$ & $\begin{array}{c}\text { start at embryo } \\
\text { stage- }-36 / 48 / 60 / 72 / 96 \mathrm{hpf}\end{array}$ & $\begin{array}{l}* * 2.8 \mathrm{mg} / \mathrm{L}: 60,72,96 \mathrm{hpf} ; \\
* * 7 \mathrm{mg} / \mathrm{L} \mathrm{\&}^{* *} 14 \mathrm{mg} / \mathrm{L}: \\
36,48,60,72,96 \mathrm{hpf}\end{array}$ & {$[42]$} \\
\hline
\end{tabular}

\subsection{Sublethal Effects}

\subsubsection{Developmental and Morphological Defects}

To assess sublethal effects of a toxic substance, development toxicity and teratogenic toxicity in zebrafish embryos were employed. Common morphological abnormalities included altered hatching rate, altered body size, body weight and heart rate, body curvature, induction of yolk sac and pericardial edema, spontaneous movement inhibition, malformation in swim bladder as well as pigmentation [35,43].

An increased deformity rate was reported in DEHP-exposed zebrafish embryos $[37,38,41]$. The deformity rate reached $20 \%$ in zebrafish embryos treated with $10 \mathrm{mg} / \mathrm{L}$ DEHP, where swimming-bladder inflation was the most commonly observed defect [41]. Pu et al. and Hamid et al. coincidently reported bent spine as one of the discernable phenotypes [37,38]. DEHP treatment with $2.5 \mu \mathrm{g} / \mathrm{L}$ significantly reduced the hatching rate of zebrafish embryos at 48 and $72 \mathrm{hpf}$ compared to the control [44]. In a separate study, a hatching rate $62.4 \%$ was reported in the DEHP-treated group at $72 \mathrm{hpf}$, with the concentration as low as $0.5 \mu \mathrm{g} / \mathrm{L}$ [39]. On the other hand, body length reduction was reported in DEHP-exposed zebrafish embryos [44-47]. Tran et al. reported that the body lengths of $120 \mathrm{hpf}$ zebrafish embryos were decreased upon DEHP exposures to the highest tested concentration $(100 \mathrm{mg} / \mathrm{L})$, which were however not significantly different after DEHP exposures to lower concentrations $(0.5 \mu \mathrm{g} / \mathrm{L}-10 \mathrm{mg} / \mathrm{L})$ [46]. Kinch et al. demonstrated that DEHP exposures induced a more serious effect on the morphology at earlier time points (3-24 hpf and 3-48 hpf) than at later time points (3-72 hpf) [45]. Exposures from 3 to $24 \mathrm{hpf}$ to $5.2 \mathrm{nM}$ DEHP significantly reduced the body length, tail length as well as yolk extension length of zebrafish embryos compared to the 
control, while no effects were observed with DEHP exposures at 3-48 hpf and 3-72 hpf [45]. Opposite results were obtained by Ustundag et al. and Mu et al. in that DEHP could cause yolk sac edema with longer treatment durations [44,48]. Mu et al. found that $250 \mu \mathrm{g} / \mathrm{L}$ of DEHP significantly induced yolk sac edema in $48 \mathrm{hpf}$ embryos as well as increased ratios of yolk sac area to fish body area in DEHP-dosed embryos when compared with control embryos [48]. In a separate study, Mu et al. reported that exposure to as low as $2.5 \mu \mathrm{g} / \mathrm{L}$ of DEHP could cause yolk sac edema in $72 \mathrm{hpf}$ embryos [44]. Kinch et al. found that the forebrain lengths of embryos treated with DEHP from 3 to $48 \mathrm{hpf}$ were significantly reduced by $10 \%$ when compared to the negative controls [45]. In the same study, upon exposure to DEHP or thyroid hormone, the head length was decreased by $20 \%$ relative to the controls when exposed from 3 to $24 \mathrm{hpf}$. The results suggested that the head morphology might be changed through interactions with thyroid hormone receptors [45]. Hyperemia and dark pigmentation were also detected in DEHP-exposed zebrafish embryos [41]. For MEHP exposures, Park et at. reported effective concentrations (EC) based on biological responses (mortality and abnormality) of zebrafish embryos after exposures to eight different concentrations of MEHP (namely, 0, 0.1, 1.6, 3.1, 6.3, 12.5, 25 and $50 \mu \mathrm{g} / \mathrm{mL}$ ) for 6 days [49]. No observed effect concentration (NOEC), EC10, EC50 and EC100 were determined as <6.09, 9.77, 29.98 and $50 \mu \mathrm{g} / \mathrm{mL}$, respectively [49]. Kamstra et al. reported reduction in body length [50], while Sant et al. found abnormalities in the swim bladder in MEHP-exposed larvae [51]. On the other hand, Lu et al. revealed decreases in the hatching rate, heart rate and body length as well as increased deformity in MEHP-exposed embryos when compared to the controls [42]. Table 2 summarizes developmental and morphological defects from acute exposures to DEHP or MEHP in zebrafish embryos.

Table 2. Developmental and morphological defects from acute exposures to (a) DEHP and (b) MEHP in zebrafish embryos. * The concentration was converted from $\mathrm{nM}$ or $\mu \mathrm{M}$ using the molar mass of DEHP $390.57 \mathrm{~g} / \mathrm{mol}$. ** The concentration was converted from $\mathrm{nM}$ or $\mu \mathrm{M}$ using the molar mass of MEHP $278.34 \mathrm{~g} / \mathrm{mol}$.

\begin{tabular}{|c|c|c|c|c|}
\hline \multicolumn{5}{|l|}{ (a) DEHP } \\
\hline Endpoint & Lowest Effective Dose & Exposure & Endpoint Time & References \\
\hline \multirow[t]{2}{*}{ hatching delayed } & $0.5 \mu \mathrm{g} / \mathrm{L}$ & $27-72 \mathrm{hpf}$ & $72 \mathrm{hpf}$ & [39] \\
\hline & $2.5 \mu \mathrm{g} / \mathrm{L}$ & $4-48 / 72 \mathrm{hpf}$ & $48,72 \mathrm{hpf}$ & {$[44]$} \\
\hline \multirow{2}{*}{ deformity rate increased } & $25 \mu \mathrm{g} / \mathrm{L}$ & $3-168 \mathrm{hpf}$ & $168 \mathrm{hpf}$ & [38] \\
\hline & $200 \mathrm{mg} / \mathrm{L}$ & $1-168 \mathrm{hpf}$ & $168 \mathrm{hpf}$ & [37] \\
\hline \multirow[t]{3}{*}{ body length decreased } & $* 2.0 \mu \mathrm{g} / \mathrm{L}$ & $3-24 \mathrm{hpf}$ & $24 \mathrm{hpf}$ & [45] \\
\hline & $100 \mathrm{mg} / \mathrm{L}$ & $2-120 \mathrm{hpf}$ & $120 \mathrm{hpf}$ & [46] \\
\hline & $100 \mathrm{mg} / \mathrm{L}$ & $6-168 \mathrm{hpf}$ & $168 \mathrm{hpf}$ & [47] \\
\hline tail length decreased & $* 2.0 \mu \mathrm{g} / \mathrm{L}$ & $3-24 \mathrm{hpf}$ & $24 \mathrm{hpf}$ & {$[45]$} \\
\hline swim bladder inflation inhibited & $500 \mu \mathrm{g} / \mathrm{L}$ & $72-168$ hpf & $168 \mathrm{hpf}$ & [41] \\
\hline \multirow[t]{2}{*}{ yolk sac edema } & $2.5 \mu \mathrm{g} / \mathrm{L}$ & $4-72$ hpf & $72 \mathrm{hpf}$ & [44] \\
\hline & $50 \mu \mathrm{g} / \mathrm{L}$ & $2-48 \mathrm{hpf}$ & $48 \mathrm{hpf}$ & {$[48]$} \\
\hline yolk extension length decreased & $* 2.0 \mu \mathrm{g} / \mathrm{L}$ & $3-24 \mathrm{hpf}$ & $24 \mathrm{hpf}$ & [45] \\
\hline hyperemia & $10 \mathrm{mg} / \mathrm{L}$ & $72-168 \mathrm{hpf}$ & $168 \mathrm{hpf}$ & [41] \\
\hline dark pigmentation & $10 \mathrm{mg} / \mathrm{L}$ & $72-168 \mathrm{hpf}$ & $168 \mathrm{hpf}$ & [41] \\
\hline forebrain length decreased & $* 2.0 \mu \mathrm{g} / \mathrm{L}$ & $3-48 \mathrm{hpf}$ & $48 \mathrm{hpf}$ & {$[45]$} \\
\hline head width decreased & $* 2.0 \mu \mathrm{g} / \mathrm{L}$ & $3-24 \mathrm{hpf}$ & $24 \mathrm{hpf}$ & {$[45]$} \\
\hline
\end{tabular}


Table 2. Cont.

\begin{tabular}{|c|c|c|c|c|}
\hline \multicolumn{5}{|l|}{ (b) MEHP } \\
\hline Endpoint & Lowest Effective Dose & Exposure & Endpoint Time & References \\
\hline hatching delayed & $* * 2.8 \mathrm{mg} / \mathrm{L}$ & $4-76 \mathrm{hpf}$ & $76 \mathrm{hpf}$ & [42] \\
\hline deformity rate increased & $* * 14 \mathrm{mg} / \mathrm{L}$ & $4-76 \mathrm{hpf}$ & $76 \mathrm{hpf}$ & [42] \\
\hline body length decreased & $* * 7.0 \mathrm{mg} / \mathrm{L}$ & $4-76 \mathrm{hpf}$ & $76 \mathrm{hpf}$ & [42] \\
\hline body length decreased & $* * 8.4 \mathrm{mg} / \mathrm{L}$ & $\begin{array}{l}\text { start at embryo } \\
\text { stage-3/6 dpf }\end{array}$ & $3 / 6 \mathrm{dpf}$ & {$[50]$} \\
\hline swim bladder abnormality & $200 \mu \mathrm{g} / \mathrm{L}$ & $6-96 \mathrm{hpf}$ & $96 \mathrm{hpf}$ & [51] \\
\hline $\begin{array}{c}\text { no observed effect } \\
\text { concentration (NOEC) }\end{array}$ & $<6.09 \mathrm{mg} / \mathrm{L}$ & 6-144 hpf & $144 \mathrm{hpf}$ & [49] \\
\hline effective concentration, $10 \%$ (EC10) & $9.77 \mathrm{mg} / \mathrm{L}$ & 6-144 hpf & $144 \mathrm{hpf}$ & [49] \\
\hline effective concentration, $50 \%$ (EC50) & $29.98 \mathrm{mg} / \mathrm{L}$ & $6-144 \mathrm{hpf}$ & $144 \mathrm{hpf}$ & [49] \\
\hline effective concentration, $100 \%$ (EC100) & $50.0 \mathrm{mg} / \mathrm{L}$ & $6-144 \mathrm{hpf}$ & $144 \mathrm{hpf}$ & [49] \\
\hline
\end{tabular}

\subsubsection{Cardiovascular Toxicity}

Studies report that DEHP could impose cardiovascular toxicity to zebrafish embryos. Treatment with $250 \mu \mathrm{g} / \mathrm{L}$ DEHP induced intense apoptotic signals in the heart region in zebrafish embryos at $72 \mathrm{hpf}$ relative to the control [52]. On the other hand, DEHP was reported to induce pericardial edema in zebrafish embryos [41,44,52]. Pericardial edema was observed at 72 or $96 \mathrm{hpf}$ after treatment with DEHP in the $\mu \mathrm{g} / \mathrm{L}$ range $[44,52]$. Exposure to a higher DEHP concentration $(10 \mathrm{mg} / \mathrm{L})$ from 72 to $168 \mathrm{hpf}$ also led to the same effect [41]. However, effects on the heart rate induced by DEHP were different when lower (in the $\mu \mathrm{g} / \mathrm{L}$ range) or higher (in the $\mathrm{mg} / \mathrm{L}$ range) doses were used. The heart rate in zebrafish embryos has been widely used as an endpoint for assessing heart toxicity. Pu et al. and $\mathrm{Lu}$ et al. demonstrated that DEHP doses in the $\mathrm{mg} / \mathrm{L}$ range could reduce the heart rate in embryos at 3 days post-fertilization (dpf) [37,42]. In contrast, the heart rate was significantly increased in embryos at a later development stage (168 hpf) upon treatment with lower DEHP doses (25 and $50 \mu \mathrm{g} / \mathrm{L}$ ) [38]. For MEHP exposure, Lu et al. reported reduction of heart rate in embryos upon treatment with MEHP in the $\mathrm{mg} / \mathrm{L}$ range [42]. Table 3 summarizes the cardiovascular toxicity from acute exposures to DEHP or MEHP on zebrafish embryos.

Table 3. Cardiovascular toxicity from acute exposures to (a) DEHP and (b) MEHP on zebrafish. * The concentration was converted from $\mathrm{nM}$ or $\mu \mathrm{M}$ using the molar mass of DEHP $390.57 \mathrm{~g} / \mathrm{mol}$. ** The concentration was converted from nM or $\mu \mathrm{M}$ using the molar mass of MEHP $278.34 \mathrm{~g} / \mathrm{mol}$.

(a) DEHP

\begin{tabular}{|c|c|c|c|c|}
\hline Endpoint & Lowest Effective Dose & Exposure & Endpoint Time & References \\
\hline \multirow[t]{2}{*}{ heart rate decreased } & *20 mg/L & $4-76 \mathrm{hpf}$ & $76 \mathrm{hpf}$ & [42] \\
\hline & $120 \mathrm{mg} / \mathrm{L}$ & $1-72 \mathrm{hpf}$ & $72 \mathrm{hpf}$ & [37] \\
\hline heart rate increased & $25,50 \mu \mathrm{g} / \mathrm{L}$ & $3-168 \mathrm{hpf}$ & $168 \mathrm{hpf}$ & [38] \\
\hline \multirow[t]{3}{*}{ pericardial edema } & $2.5 \mu \mathrm{g} / \mathrm{L}$ & $4-72 \mathrm{hpf}$ & $72 \mathrm{hpf}$ & [44] \\
\hline & $250 \mu \mathrm{g} / \mathrm{L}$ & $1.5-72 / 96 \mathrm{hpf}$ & $72,96 \mathrm{hpf}$ & [52] \\
\hline & $10 \mathrm{mg} / \mathrm{L}$ & $72-168 \mathrm{hpf}$ & $168 \mathrm{hpf}$ & [42] \\
\hline apoptosis signal increased in heart region & $250 \mu \mathrm{g} / \mathrm{L}$ & $1.5-72 \mathrm{hpf}$ & $72 \mathrm{hpf}$ & [52] \\
\hline
\end{tabular}

\section{(b) MEHP}

\begin{tabular}{cccccc}
\hline Endpoint & Lowest Effective Dose & Exposure & Endpoint Time & References \\
\hline heart rate decreased & $* * 14 \mathrm{mg} / \mathrm{L}$ & $4-76 \mathrm{hpf}$ & $76 \mathrm{hpf}$ & {$[42]$} \\
\hline
\end{tabular}

\subsubsection{Skeletal Toxicity}

DEHP has been associated with skeletal and spinal abnormalities [37,44]. Exposures to DEHP from 4 to $72 \mathrm{hpf}$ could instigate axial curvature in zebrafish embryos [44]. Bent 
spinal curvature as well as spinal dysplasia were also shown in DEHP-exposed zebrafish embryos at $168 \mathrm{hpf}$ [37]. Table 4 summarizes skeletal toxicity from acute exposure to DEHP on zebrafish embryos.

Table 4. Skeletal toxicity from acute exposure to DEHP on zebrafish embryos.

\begin{tabular}{ccccc}
\hline Endpoint & Lowest Effective Dose & Exposure & Endpoint Time & References \\
\hline bent spinal curvature & $2.5 \mu \mathrm{g} / \mathrm{L}$ & $4-72 \mathrm{hpf}$ & $72 \mathrm{hpf}$ & {$[44]$} \\
spinal dysplasia (cartilage effect) & $200 \mathrm{mg} / \mathrm{L}$ & $1-168 \mathrm{hpf}$ & $168 \mathrm{hpf}$ & {$[37]$} \\
\hline
\end{tabular}

\subsubsection{Behavioral Toxicity}

Exposures to DEHP have exerted behavioral toxicities on zebrafish embryos [37,42,46,53]. Spontaneous movement inhibition has been reported in zebrafish embryos upon DEHP exposures [37,53]. Spontaneous movement was established as an important marker to assess the developmental status and behavioral ability of zebrafish embryos, which was initiated by the spinal cord at approximately $24 \mathrm{hpf}$ and was suggested to associate with hatching [43]. In one of the related studies, zebrafish embryos were exposed to seven concentrations of DEHP $(0,10,50,90,120,150,200 \mathrm{mg} / \mathrm{L})$, and the automatic movement number in $20 \mathrm{~s}$ of the embryos was assessed using a stereomicroscope at $24 \mathrm{hpf}$. The results showed that DEHP significantly inhibited movement at higher concentrations (90-200 mg/L) [37]. Similar results were found by Qian et al. who reported an inhibitory effect on the movement of zebrafish embryos upon DEHP exposures as low as $50 \mu \mathrm{g} / \mathrm{L}$ [53]. Locomotor activity was another marker to assess the behavioral ability in zebrafish embryos. DEHP exposure was confirmed to alter locomotor activities in zebrafish embryos [42,46]. In a related study, zebrafish embryos were exposed to four concentrations of $\operatorname{DEHP}(0,10,25,50 \mu \mathrm{M})$ at $4 \mathrm{hpf}$, and after the $96 \mathrm{~h}$ exposure time point, the swimming activities were recorded using the Zebralab Video-Track system (ViewPoint Life Science, France) [42]. The results indicated that an exposure to $50 \mu \mathrm{M}$ DEHP could significantly inhibit the locomotor activity compared to the control [42]. In a separate study, the locomotor activities under alternating light-dark conditions of DEHP-treated zebrafish embryos at $120 \mathrm{hpf}$ were evaluated via the ZebraBox tracking system (ViewPoint Life Science, France) [46]. Suppression of locomotor activities was reported in DEHP-exposed embryos under the dark condition, while stimulation of locomotor activities was found under the light condition [46]. Together, the lowest effective concentration of DEHP in inhibition of locomotor activity of zebrafish embryos was $5 \mu \mathrm{g} / \mathrm{L}$ as reported by Tran et al. [46]. As mentioned in Section 2.2.1, morphological developmental effects were induced upon DEHP exposures to as low as $2.0 \mu \mathrm{g} / \mathrm{L}$ ( $5.2 \mathrm{nM}$ ), with the observable body length, tail length, yolk sac extension length, forebrain length and head width decreased as reported by Kinch et al. [45]. From available data, the dose of DEHP, which triggered morphological effects, was lower than that which inhibited locomotor activity in zebrafish embryos. No existing data showed effect concentrations in locomotor activity at exposure levels where no morphological or developmental abnormalities were observed. More studies are required for understanding the relationship between morphological and developmental aberrations and behavioral toxicity in zebrafish embryos. Table 5 summarizes the behavioral toxicity from acute exposures to DEHP or MEHP on zebrafish embryos. 
Table 5. Behavioral toxicity from acute exposures to (a) DEHP and (b) MEHP on zebrafish embryos. * The concentration was converted from $\mathrm{nM}$ or $\mu \mathrm{M}$ using the molar mass of DEHP $390.57 \mathrm{~g} / \mathrm{mol}$. ${ }^{*}$ The concentration was converted from $\mathrm{nM}$ or $\mu \mathrm{M}$ using the molar mass of MEHP $278.34 \mathrm{~g} / \mathrm{mol}$.

\begin{tabular}{|c|c|c|c|c|}
\hline Endpoint & Lowest Effective Dose & Exposure & Endpoint Time & References \\
\hline $\begin{array}{l}\text { spontaneous movement decreased (no. of } \\
\text { spontaneous movements in } 20 \mathrm{~s} \text { ) }\end{array}$ & $50 \mu \mathrm{g} / \mathrm{L}$ & $2-24 \mathrm{hpf}$ & $24 \mathrm{hpf}$ & {$[53]$} \\
\hline movement inhibition & $90 \mathrm{mg} / \mathrm{L}$ & $1-24 \mathrm{hpf}$ & $24 \mathrm{hpf}$ & [37] \\
\hline locomotor activity inhibited & *20 mg/L & $4-100 \mathrm{hpf}$ & $100 \mathrm{hpf}$ & {$[42]$} \\
\hline locomotor activity (dark) (bursting) decreased & $5 \mu \mathrm{g} / \mathrm{L}$ & $2-120 \mathrm{hpf}$ & $120 \mathrm{hpf}$ & [46] \\
\hline locomotor activity (dark) (cruising) decreased & $5 \mu \mathrm{g} / \mathrm{L}$ & $2-120 \mathrm{hpf}$ & $120 \mathrm{hpf}$ & [46] \\
\hline locomotor activity (light) (swimming) increased & $10 \mathrm{mg} / \mathrm{L}$ & $2-120 \mathrm{hpf}$ & $120 \mathrm{hpf}$ & [46] \\
\hline locomotor activity (light) (cruising) increased & $10 \mathrm{mg} / \mathrm{L}$ & $2-120 \mathrm{hpf}$ & $120 \mathrm{hpf}$ & [46] \\
\hline locomotor activity (light) (freezeing) increased & $1 \mathrm{mg} / \mathrm{L}$ & $2-120 \mathrm{hpf}$ & $120 \mathrm{hpf}$ & [46] \\
\hline
\end{tabular}

(b) MEHP

\begin{tabular}{ccccc}
\hline Endpoint & Lowest Effective Dose & Exposure & Endpoint Time & References \\
\hline locomotor activity inhibited & $* * 14 \mathrm{mg} / \mathrm{L}$ & $4-100 \mathrm{hpf}$ & $100 \mathrm{hpf}$ & {$[42]$} \\
\hline
\end{tabular}

\subsection{Regulation of Genes and Possible Mechanisms}

In Section 2.2, we summarized the sublethal effects induced by DEHP or MEHP in terms of developmental and morphological defects, cardiovascular, skeletal and behavioral effects. The mechanisms behind DEHP- or MEHP-induced effects on zebrafish embryos are important for understnading the mode of action. DEHP was reported to change gene expression in zebrafish embryos, which was revealed using different techniques, including immunohistochemical staining and reverse transcription polymerase chain reaction (RTPCR) analyses. Ustundag et al. studied the effect on gene expression upon the exposure of $2.5 \mu \mathrm{g} / \mathrm{L}$ of DEHP to zebrafish embryos from 4 to $48 \mathrm{hpf}$. Immunohistochemical staining was applied to examine the expressions PCNA, Wnt3a and $\beta$-catenin genes in zebrafish embryos [44]. Intense staining of PCNA, Wnt3a and $\beta$-catenin were observed in the DEHP group compared to the weak staining shown in the control group. The authors further conducted reverse transcription polymerase chain reaction (RT-PCR) analysis to examine gene expressions in $72 \mathrm{hpf}$ zebrafish embryos. Expression of gsk $3 \beta$ was significantly increased in the DEHP group relative to the control [44]. Studies also reported that DEHP altered gene expressions related to the skeletal development pathway in $96 \mathrm{hpf}$ zebrafish embryos [37,53]. Exposure of environmentally relevant concentrations of DEHP at $50 \mu \mathrm{g} / \mathrm{L}$ significantly upregulated the expressions of genes in $96 \mathrm{hpf}$ zebrafish embryos involved in skeletal development in terms of skeleton (spp1), notochord (ngs, col8a1a) and muscle (klhl41a, smyd2b, stac3) [53]. However, the expression of colsa1a was significantly reduced by DEHP at $250 \mu \mathrm{g} / \mathrm{L}$. Together, the results demonstrated that DEHP could lead to abnormal development of the spine and skeletal system and the authors proposed that different transcriptional effects could be induced under different concentrations [53]. Pu et al. also reported that a higher concentration $(200 \mathrm{mg} / \mathrm{L})$ of DEHP activated the expression levels of four major skeletal-related genes (sp7, runx2b, gpc4a, shha) in zebrafish embryos [37].

On the other hand, multi-omics approaches were also employed to investigate the mechanisms of DEHP-induced developmental toxicities [48,52]. Omics approaches in biology, including genomics, epigenomics, transcriptomics, proteomics, lipidomics and metabolomics, can reveal alterations in different domains upon toxicant exposures and provide insights into possible mechanisms as well as potential toxic effects and diseases [54]. Mu et al. examined the effects on zebrafish embryos upon exposures to $50 \mu \mathrm{g} / \mathrm{L}$ of DEHP through transcriptomic, proteomic and lipidomic approaches [48]. From transcriptomic profiling analysis, significant alteration was observed in expression of transcripts related to different biological processes involved in lipid metabolism and skeletal development, e.g., steroid binding, lipid binding, lipid transport, fatty-acid metabolism, skeletal muscle tissue 
development, stress response as well as chemokine activity [48]. On the other hand, the data from proteomic profiling analysis suggest significant changes in the levels of 235 proteins (217 up-regulated and 18 down-regulated) [48]. The data revealed that DEHP significantly induced various processes in zebrafish embryos, including lipase activity regulation, lipid absorption, lipid catabolism and lipid metabolism [48]. REVIGO similarity analysis was further applied, which revealed that lipid digestion, lipid metabolism, lipid transport and lipase activity regulation were the major pathways activated by DEHP exposures [48]. From lipidomic profiling analysis, among 207 identified lipid species in zebrafish embryos, DEHP was shown to significantly lower the levels of neutral glycosphingolipids (Creg1), cholesterol esters (Che), diglycerides (DG), triglycerides (TG) and fatty acids (FA) [48]. The study also reported that DEHP altered the expression of protein levels involved in immune responses (TNF $\alpha, \mathrm{NF}-\mathrm{k} \beta, \mathrm{il}-1 \beta, \mathrm{il}-8, \mathrm{tp} 63)$ [48]. Based on these findings, the authors inferred that DEHP-induced immune response might be a result of disruption of lipid homeostasis [48]. In a separate study, $\mathrm{Mu}$ et al. further investigated possible developmental pathways upon exposures to $50 \mu \mathrm{g} / \mathrm{L}$ of DEHP via transcriptomic and DNA methylation profile analysis, particularly the genes involved in heart development [52]. From transcriptomic analyses, among 32,477 genes in the reference genome of zebrafish, the research group reported that 371 transcripts (234 up-regulated and 137 down-regulated) were significantly altered in embryos after their exposure to $50 \mu \mathrm{g} / \mathrm{L}$ DEHP, followed by the gene ontology analysis. [52]. The results showed that exposure to $50 \mu \mathrm{g} / \mathrm{L}$ of DEHP significantly induced pathways of steroid binding (paqr5b, nr1h4, fabp10a), cyclase activator activity (gucala, gucald), actomyosin structure organization (klhl41a, csrp3, cnn1b, ctnt), chemokine receptor binding (ccl27a, ccl39.3), myofibril assembly (csrp3, klhl41a, ctnt), notochord development (colsala, $n g s, f b n 2 b)$, skeletal system development (spp1), heart contraction $(s m y d 2 b, c s r p 3)$ as well as heart process (smyd2b, csrp3), which were related to heart development [52]. Differential gene transcriptions, including $n p p a, M y 17, T b x 5 b$, smyd2b, klhl41a, ctnt and cmlc1 were altered in embryos after DEHP exposures, which were further confirmed using quantitative polymerase chain reaction (qPCR) [52]. In the same study, the global change of DNA methylation in zebrafish embryos was assessed using methylated DNA immunoprecipitation sequencing (MeDIP-Seq). Mu et al. also reported significant hypomethylation of nppa, ctnt and hypermethylation of $t b x 5 b$ in DEHPexposed zebrafish embryos, which were related to heart development [52]. Comparisons on transcriptomic and DNA methylation profiles suggested that transcriptional alteration of gene might be associated with modified DNA methylation [52].

Junaid et al. studied the toxicity in zebrafish embryos induced by acute exposures to DEHP at environmentally relevant concentrations $(0-400 \mu \mathrm{g} / \mathrm{L})$ [55]. The results showed that $400 \mu \mathrm{g} / \mathrm{L}$ of DEHP could activate the PI3K-AKT-mTOR pathway in zebrafish embryos as evidenced by significant upregulation of the transcripts of key genes involved in the pathway (pik3r1, akt1, mtor, ps6kb) [55]. Junaid et al. further used the cyp1a transgenic zebrafish to monitor the effect of DEHP exposure on the AhR activity. Concentrationdependent increases in the levels of fluorescent signals in DEHP-exposed Tg(cyp1a:gfp) zebrafish embryos were observed, which indicated that short-term low-concentration exposures to DEHP could induce AhR activity in the embryos [55]. Do et al. also employed transgenic zebrafish as the model particularly to explore possible mechanisms of DEHPinduced abnormal neurobehavior. After confirming the inhibition of locomotor activities in DEHP-exposed zebrafish embryos, as described in Section 2.2.4., the authors further found significant reduction in fluorescent intensity in the transgenic zebrafish $\mathrm{Tg}$ ( $\mathrm{HuC:eGFP)}$ upon DEHP exposures [46]. The study further reported the potential of DEHP in interfering with neurotransmission as evidenced through upregulation of ache and down regulation of th gene expression, which were involved in the dopamine system [46].

Regarding MEHP exposures, Sant et al. observed that exposures to $200 \mu \mathrm{g} / \mathrm{L}$ of MEHP significantly enhanced vacuolization and types of vacuolization in the livers of 96 hpf zebrafish larvae through histological analysis [51]. Furthermore, the zebrafish larvae were exposed to $200 \mu \mathrm{g} / \mathrm{L}$ of MEHP from 6 to $120 \mathrm{hpf}$ and were assessed on the 15th day 
through different endpoints. The lipid contents in the zebrafish larvae were assessed via red O staining, which revealed that MEHP exposures significantly increased lipid accumulation in the livers and brains in the larvae compared to the control group [51]. Expression of peroxisome proliferator-activated receptor (PPAR) alpha target fabp1a1 was also found to have increased in MEHP-exposed larvae [51]. A parallel experiment was also conducted to investigate the involvement of nuclear factor erythroid 2-related factor 2 (Nrf2) signaling in MEHP-induced larval steatosis using the nrf2a mutant zebrafish. However, the results demonstrated that MEHP-induced larval steatosis was independent of Nrf2 signaling [51]. Table 6 summarizes the regulation of genes and possible mechanisms from acute exposures to DEHP or MEHP on zebrafish embryos.

Table 6. Regulation of gene and possible mechanisms from acute exposures to (a) DEHP and (b) MEHP on zebrafish embryos.

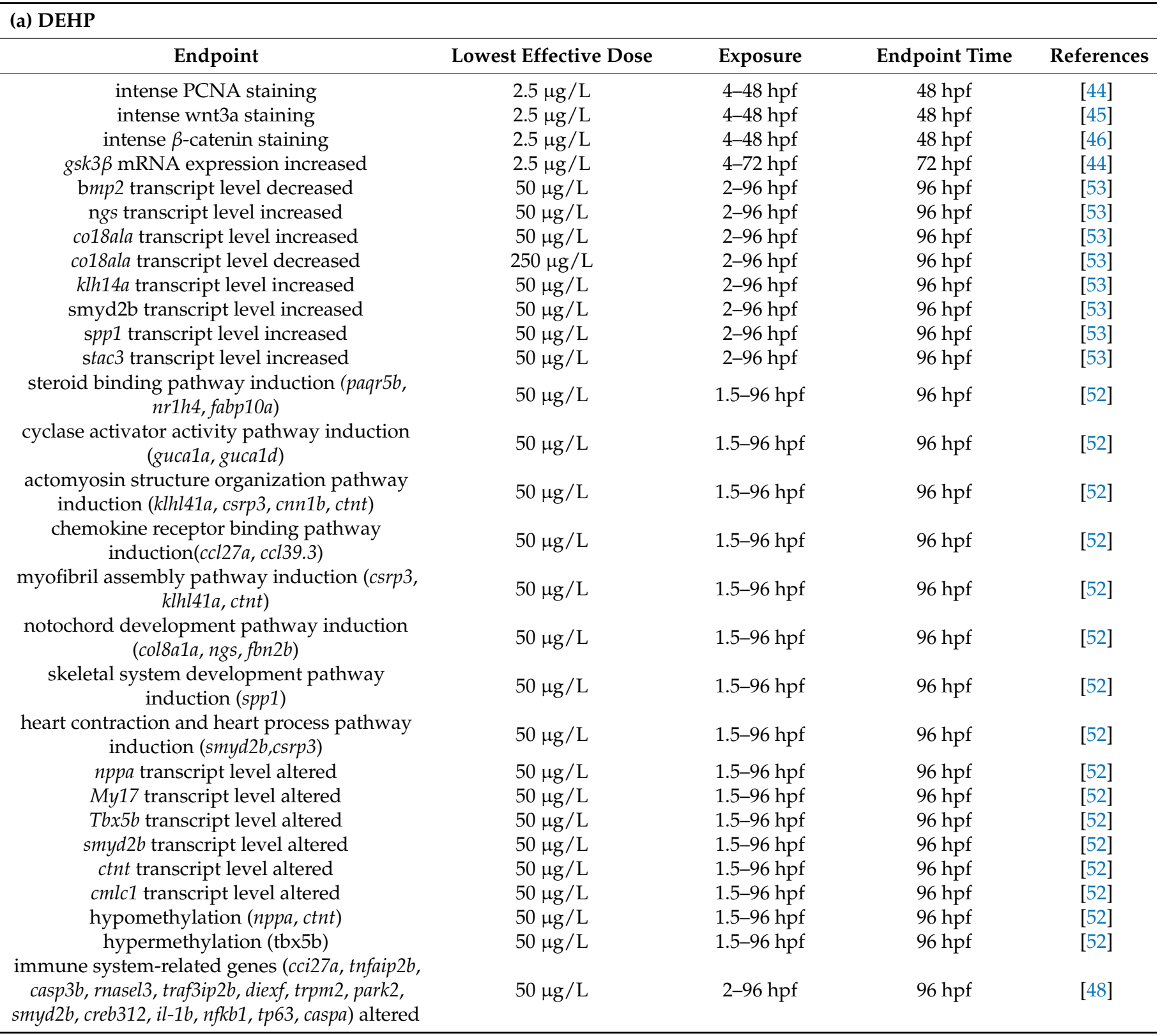


Table 6. Cont.

\begin{tabular}{|c|c|c|c|c|}
\hline \multicolumn{5}{|l|}{ (a) DEHP } \\
\hline Endpoint & Lowest Effective Dose & Exposure & Endpoint Time & References \\
\hline $\begin{array}{l}\text { lipid metabolism and skeletal development } \\
\text { related genes (paqr5b, nr1h4, gc, fabp10a, esyt3, } \\
\text { zfos-411a11.2, alox5a, apoba, atp8b1, osbp19, } \\
\text { ch25hl1.2, gfpt1, klhl41a, klhl40b, stac3, ucmab, } \\
\text { spp1, caspa, hapln1b) altered }\end{array}$ & $50 \mu \mathrm{g} / \mathrm{L}$ & 2-96 hpf & $96 \mathrm{hpf}$ & [48] \\
\hline$s p 7$ transcript level increased & $200 \mathrm{mg} / \mathrm{L}$ & $1-168 \mathrm{hpf}$ & $168 \mathrm{hpf}$ & [37] \\
\hline run $x 2 b$ transcript level increased & $200 \mathrm{mg} / \mathrm{L}$ & $1-168 \mathrm{hpf}$ & $168 \mathrm{hpf}$ & [38] \\
\hline gpc4a transcript level increased & $200 \mathrm{mg} / \mathrm{L}$ & $1-168 \mathrm{hpf}$ & $168 \mathrm{hpf}$ & [39] \\
\hline sha transcript level increased & $200 \mathrm{mg} / \mathrm{L}$ & $1-168 \mathrm{hpf}$ & $168 \mathrm{hpf}$ & {$[40]$} \\
\hline $\begin{array}{l}\text { elav13 expression decreased, Fluorescence } \\
\text { intensity reduction inTg (HuC:eGFP) }\end{array}$ & $500 \mu \mathrm{g} / \mathrm{L}$ & $2-72 \mathrm{hpf}$ & $72 \mathrm{hpf}$ & {$[46]$} \\
\hline ache transcript level increased & $50 \mu \mathrm{g} / \mathrm{L}$ & $2-120 \mathrm{hpf}$ & $120 \mathrm{hpf}$ & [46] \\
\hline th transcript level decreased & $500 \mu \mathrm{g} / \mathrm{L}$ & $2-120 \mathrm{hpf}$ & $121 \mathrm{hpf}$ & [46] \\
\hline pik3r1 mRNA expression increased & $400 \mu \mathrm{g} / \mathrm{L}$ & $2-168 \mathrm{hpf}$ & $168 \mathrm{hpf}$ & [55] \\
\hline akt1 mRNA expression increased & $400 \mu \mathrm{g} / \mathrm{L}$ & $2-168 \mathrm{hpf}$ & $168 \mathrm{hpf}$ & [55] \\
\hline mtor $m R N A$ expression increased & $400 \mu \mathrm{g} / \mathrm{L}$ & $2-168 \mathrm{hpf}$ & $168 \mathrm{hpf}$ & [55] \\
\hline$p s 6 \mathrm{~kb} m R N A$ expression increased & $200 \mu \mathrm{g} / \mathrm{L}$ & $2-168 \mathrm{hpf}$ & $168 \mathrm{hpf}$ & [55] \\
\hline $\begin{array}{l}\text { AhR activity induction, Fluorescence intensity } \\
\text { increased in } \operatorname{Tg}(\text { cypla:gfp) }\end{array}$ & $33 \mu \mathrm{g} / \mathrm{L}$ & $2-120 \mathrm{hpf}$ & $120 \mathrm{hpf}$ & {$[55]$} \\
\hline Cerg1 level decreased & $50 \mu \mathrm{g} / \mathrm{L}$ & 2-96 hpf & $96 \mathrm{hpf}$ & [48] \\
\hline Che level decreased & $50 \mu \mathrm{g} / \mathrm{L}$ & $2-96 \mathrm{hpf}$ & $96 \mathrm{hpf}$ & [48] \\
\hline DG level decreased & $50 \mu \mathrm{g} / \mathrm{L}$ & 2-96 hpf & $96 \mathrm{hpf}$ & [48] \\
\hline TG level decreased & $50 \mu \mathrm{g} / \mathrm{L}$ & $2-96 \mathrm{hpf}$ & $96 \mathrm{hpf}$ & [48] \\
\hline FA level decreased & $50 \mu \mathrm{g} / \mathrm{L}$ & $2-96 \mathrm{hpf}$ & $96 \mathrm{hpf}$ & [48] \\
\hline $\begin{array}{c}\text { lipase activity regulation, lipid absorption, lipid } \\
\text { catabolism, lipid digestion, lipid metabolism } \\
\text { and lipid transport increased }\end{array}$ & $50 \mu \mathrm{g} / \mathrm{L}$ & $2-96 \mathrm{hpf}$ & $96 \mathrm{hpf}$ & {$[48]$} \\
\hline \multicolumn{5}{|l|}{ (b) MEHP } \\
\hline Endpoint & Lowest Effective Dose & Exposure & Endpoint Time & References \\
\hline $\begin{array}{l}\text { increased vacuolization and type of } \\
\text { vacuolization in liver }\end{array}$ & $200 \mu \mathrm{g} / \mathrm{L}$ & 6-96 hpf & $96 \mathrm{hpf}$ & [51] \\
\hline lipid accumulation in liver \& brain & $200 \mu \mathrm{g} / \mathrm{L}$ & $6-120 \mathrm{hpf}$ & $15 \mathrm{dpf}$ & [51] \\
\hline fabp1a1 expression increased & $200 \mu \mathrm{g} / \mathrm{L}$ & $6-120 \mathrm{hpf}$ & $15 \mathrm{dpf}$ & [51] \\
\hline
\end{tabular}

\section{Potential Long-Term Effects Induced by Acute Exposure}

In addition to acute developmental and teratogenic toxicity in zebrafish embryos, assessments through various biological endpoints also revealed long-term effects. Examples of established biomarkers in the fish model included immune modulation, endocrine disruption as well as genotoxicity [56]. In this section, we reviewed potential long-term effects induced by DEHP exposure in zebrafish embryos in terms of oxidative stress, apoptosis and genotoxicity, transgenic effect as well as endocrine disruption.

\subsection{Induction of Oxidative Stress}

It was well established that oxidant-antioxidant balance played a critical role in organisms to maintain cellular development growth and survival. DEHP was found to upset the oxidant-antioxidant balance in zebrafish embryos [38,40,42]. Lu et al. reported the increased ROS generation and decreased superoxide dismutase (SOD) activity in $28 \mathrm{hpf}$ embryos after DEHP and MEHP exposures [42]. In a separate study, enhanced expression of oxidative stress-related genes (CAT, CuSOD, MnSOD) were reported in zebrafish embryos upon exposures to $50 \mu \mathrm{g} / \mathrm{L}$ of DEHP [38]. Upset of oxidant-antioxidant balance in embryos was also reported in DEHP-exposed zebrafish embryos in terms of increased lipid peroxidation (LPO) and decreased glutathione-S-transferase (GST) levels 
exposed to as low as $2.5 \mu \mathrm{g} / \mathrm{L}$ of DEHP [40]. Table 7 summarizes the induction of oxidative stress from acute exposures to DEHP or MEHP on zebrafish embryos.

Table 7. Induction of oxidative stress from acute exposures to (a) DEHP and (b) MEHP on zebrafish embryos. * The concentration was converted from $\mathrm{nM}$ or $\mu \mathrm{M}$ using the molar mass of DEHP $390.57 \mathrm{~g} / \mathrm{mol}$. ** The concentration was converted from $\mathrm{nM}$ or $\mu \mathrm{M}$ using the molar mass of MEHP $278.34 \mathrm{~g} / \mathrm{mol}$.

\begin{tabular}{|c|c|c|c|c|}
\hline \multicolumn{5}{|l|}{ (a) DEHP } \\
\hline Endpoint & Lowest Effective Dose & Exposure & Endpoint Time & References \\
\hline lipid peroxidation (LPO) increased & $2.5 \mu \mathrm{g} / \mathrm{L}$ & start at embryo stage $-72 \mathrm{hpf}$ & $72 \mathrm{hpf}$ & [40] \\
\hline glutathione S-transferase (GST) decreased & $2.5 \mu \mathrm{g} / \mathrm{L}$ & start at embryo stage $-72 \mathrm{hpf}$ & $72 \mathrm{hpf}$ & [40] \\
\hline CAT expression increased & $50 \mu \mathrm{g} / \mathrm{L}$ & $3-96 \mathrm{hpf}$ & $96 \mathrm{hpf}$ & [38] \\
\hline CuSOD expression increased & $50 \mu \mathrm{g} / \mathrm{L}$ & $3-96 \mathrm{hpf}$ & $96 \mathrm{hpf}$ & [39] \\
\hline$M n S O D$ expression increased & $50 \mu \mathrm{g} / \mathrm{L}$ & $3-96 \mathrm{hpf}$ & $96 \mathrm{hpf}$ & [40] \\
\hline ROS generation increased & * $20 \mathrm{mg} / \mathrm{L}$ & $4-28 \mathrm{hpf}$ & $28 \mathrm{hpf}$ & [42] \\
\hline SOD activity decreased & * $20 \mathrm{mg} / \mathrm{L}$ & $4-28 \mathrm{hpf}$ & $28 \mathrm{hpf}$ & [42] \\
\hline \multicolumn{5}{|l|}{ (b) МEHP } \\
\hline Endpoint & Lowest Effective Dose & Exposure & Endpoint Time & References \\
\hline ROS generation increased & ** $14 \mathrm{mg} / \mathrm{L}$ & $4-28 \mathrm{hpf}$ & $28 \mathrm{hpf}$ & [42] \\
\hline SOD activity decreased & $* * 14 \mathrm{mg} / \mathrm{L}$ & $4-28 \mathrm{hpf}$ & $28 \mathrm{hpf}$ & [42] \\
\hline
\end{tabular}

\subsection{Apoptosis and Genotoxicity}

Genotoxic effects of DEHP were confirmed in various in vitro and in vivo studies and was reviewed by Caldwell, including induction of DNA damages, abnormal regulation of mitotic rate, apoptosis and cell prolifreation as well as activation of different nuclear receptors, which could contribute to cancer progression [57]. DNA damages could be induced by direct action of parental compounds of environmental contaminants or their metabolites or through indirect action by the generated reactive oxygen species (ROS) [58]. Embryos were exposed to five sublethal concentrations of DEHP (namely, 0, 0.5, 1, 5 and $10 \mathrm{mg} / \mathrm{L}$ ) from 72 to $168 \mathrm{hpf}$, and DNA damages in cells of the embryos were then analyzed using comet assay [41]. The results demonstrated that DEHP significantly induced DNA strand breaks in embryos in a concentration dependent manner, when compared to controls. Boran et al. further reported upregulation of the tumor suppressor gene $p 53$ as well as DNA repair genes rad51 and $x r c c 5$ in DEHP-exposed embryos [41]. Lu et al. further studied the involvement of the BER pathway in DEHP- and MEHP-treated zebrafish embryos through measuring the mRNA levels of genes related to the BER pathway [42]. The results showed that DEHP exposures significantly increased mRNA levels of ogg1, parp1, pcna, fen1 and lig1, while MEHP exposures significantly increased mRNA levels of ogg1, nthl1, apex1, aprp1, xrcc1, lig3, ung, pcna, fen1 and lig1, which suggested that the BER pathway played critical roles in DEHP- and MEHP-induced oxidative stress through repairing oxidative DNA damages [42].

Besides, DEHP was confirmed to induce apoptosis and alter apoptosis-related genes (cas8, cas9, pf3, bcl, bax) in zebrafish embryos [38,42,52]. Acridine orange (AO) staining was established as a widely used technique to study apoptosis in zebrafish embryos. Various studies used AO staining to investigate DEHP-induced apoptosis in zebrafish embryos [38,52]. Exposures to $250 \mu \mathrm{g} / \mathrm{L}$ of DEHP from 1.5 to $72 \mathrm{hpf}$ induced apoptotic signals in zebrafish embryos, and intense apoptotic signals were observed in the heart region [52]. Hamid et al. also observed an elevated number of apoptotic cells in DEHPtreated zebrafish embryos with a lower DEHP concentration $(50 \mu \mathrm{g} / \mathrm{L})$ and for a longer exposure (3-96 hpf) [38]. In the same study, increased mRNA levels of the apoptosis-related genes cas8, cas9, pf3 and bax were detected in DEHP-treated embryos [38]. In a separate study, mRNA expressions of bcl2 and bax were found to increase in $28 \mathrm{hpf}$ embryos upon exposures to higher concentrations of DEHP $(25-50 \mu \mathrm{M})$ [42]. The mRNA levels of $b c l 2$ and bax in zebrafish embryos were also significantly altered after MEHP exposures [42]. 
Ustundag et al. investigated the relationship between oxidant-antioxidant balance and expression of $c-m y c$, which was the gene that regulated cell proliferation and apoptosis. Increased expression of $c-m y c$ in DEHP-exposed embryos was reported, which was thus proposed as a protective mechanism to preserve oxidant-antioxidant balance in zebrafish embryos [40]. Table 8 summarizes the induction of apoptosis and genotoxicity from acute exposures to DEHP or MEHP in zebrafish embryos.

Table 8. Apoptosis and genotoxicity from acute exposures to (a) DEHP and (b) MEHP on zebrafish embryos. * The concentration was converted from $\mathrm{nM}$ or $\mu \mathrm{M}$ using the molar mass of DEHP $390.57 \mathrm{~g} / \mathrm{mol}$. ** The concentration was converted from $\mathrm{nM}$ or $\mu \mathrm{M}$ using the molar mass of MEHP $278.34 \mathrm{~g} / \mathrm{mol}$.

(a) DEHP

\begin{tabular}{|c|c|c|c|c|}
\hline Endpoint & Lowest Effective Dose & Exposure & Endpoint Time & References \\
\hline apoptosis signal increased & $50 \mu \mathrm{g} / \mathrm{L}$ & $3-96 \mathrm{hpf}$ & $96 \mathrm{hpf}$ & [38] \\
\hline apoptosis signal increased (heart region) & $250 \mu \mathrm{g} / \mathrm{L}$ & $1.5-72 \mathrm{hpf}$ & $72 \mathrm{hpf}$ & [52] \\
\hline bax mRNA expression decreased & $50 \mu \mathrm{g} / \mathrm{L}$ & 3-96 hpf & $96 \mathrm{hpf}$ & {$[38]$} \\
\hline bax mRNA expression increased & * $20 \mathrm{mg} / \mathrm{L}$ & $4-28 \mathrm{hpf}$ & $28 \mathrm{hpf}$ & [42] \\
\hline$b c l 2$ mRNA expression decreased & * $9.8 \mathrm{mg} / \mathrm{L}$ & $4-28 \mathrm{hpf}$ & $28 \mathrm{hpf}$ & [42] \\
\hline ctnt transcription level increased & $50 \mu \mathrm{g} / \mathrm{L}$ & $1.5-96 \mathrm{hpf}$ & $96 \mathrm{hpf}$ & [52] \\
\hline ctnt protein level increased & $50 \mu \mathrm{g} / \mathrm{L}$ & $1.5-96 \mathrm{hpf}$ & $96 \mathrm{hpf}$ & [52] \\
\hline nppa transcription level increased & $50 \mu \mathrm{g} / \mathrm{L}$ & $1.5-96 \mathrm{hpf}$ & $96 \mathrm{hpf}$ & [52] \\
\hline Nppa protein level increased & $50 \mu \mathrm{g} / \mathrm{L}$ & $1.5-96 \mathrm{hpf}$ & $96 \mathrm{hpf}$ & [52] \\
\hline cas 8 mRNA expression increased & $50 \mu \mathrm{g} / \mathrm{L}$ & 3-96 hpf & $96 \mathrm{hpf}$ & {$[38]$} \\
\hline cas9 mRNA expression increased & $50 \mu \mathrm{g} / \mathrm{L}$ & $3-96 \mathrm{hpf}$ & $96 \mathrm{hpf}$ & [38] \\
\hline$p f 3$ mRNA expression increased & $50 \mu \mathrm{g} / \mathrm{L}$ & 3-96 hpf & $96 \mathrm{hpf}$ & [38] \\
\hline ogg1 mRNA expression increased & * $20 \mathrm{mg} / \mathrm{L}$ & $4-28 \mathrm{hpf}$ & $28 \mathrm{hpf}$ & [42] \\
\hline parp1 mRNA expression increased & * $3.9 \mathrm{mg} / \mathrm{L}$ & $4-28 \mathrm{hpf}$ & $28 \mathrm{hpf}$ & [42] \\
\hline pcna mRNA expression increased & * $3.9 \mathrm{mg} / \mathrm{L}$ & $4-28 \mathrm{hpf}$ & $28 \mathrm{hpf}$ & [42] \\
\hline polb mRNA expression increased & * $3.9 \mathrm{mg} / \mathrm{L}$ & $4-28 \mathrm{hpf}$ & $28 \mathrm{hpf}$ & [42] \\
\hline pold mRNA expression decreased & * $3.9 \mathrm{mg} / \mathrm{L}$ & $4-28 \mathrm{hpf}$ & $28 \mathrm{hpf}$ & [42] \\
\hline fen 1 mRNA expression increased & * $20 \mathrm{mg} / \mathrm{L}$ & $4-28 \mathrm{hpf}$ & $28 \mathrm{hpf}$ & [42] \\
\hline lig1 mRNA expression increased & * $3.9 \mathrm{mg} / \mathrm{L}$ & $4-28 \mathrm{hpf}$ & $28 \mathrm{hpf}$ & {$[42]$} \\
\hline$c-m y c$ transcript level increased & $2.5 \mu \mathrm{g} / \mathrm{L}$ & start at embryo stage $-72 \mathrm{hpf}$ & $72 \mathrm{hpf}$ & [40] \\
\hline DNA breaks increased & $5 \mathrm{mg} / \mathrm{L}$ & $72-168 \mathrm{hpf}$ & $168 \mathrm{hpf}$ & {$[41]$} \\
\hline p53 mRNA expression increased & $500 \mu \mathrm{g} / \mathrm{L}$ & $72-168 \mathrm{hpf}$ & $168 \mathrm{hpf}$ & [41] \\
\hline rad51 expression increased & $1 \mathrm{mg} / \mathrm{L}$ & $72-168 \mathrm{hpf}$ & $168 \mathrm{hpf}$ & [41] \\
\hline xrcc5 expression increased & $1 \mathrm{mg} / \mathrm{L}$ & $72-168 \mathrm{hpf}$ & $168 \mathrm{hpf}$ & [41] \\
\hline
\end{tabular}

(b) MEHP

\begin{tabular}{|c|c|c|c|c|}
\hline Endpoint & Lowest Effective Dose & Exposure & Endpoint Time & References \\
\hline bax mRNA level increased & $* * 2.8 \mathrm{mg} / \mathrm{L}$ & $4-28 \mathrm{hpf}$ & $28 \mathrm{hpf}$ & [42] \\
\hline$b c l 2$ mRNA level decreased & $* * 14 \mathrm{mg} / \mathrm{L}$ & $4-28 \mathrm{hpf}$ & $28 \mathrm{hpf}$ & [42] \\
\hline ogg1 mRNA expression increased & $* * 2.8 \mathrm{mg} / \mathrm{L}$ & $4-28 \mathrm{hpf}$ & $28 \mathrm{hpf}$ & [42] \\
\hline nthl1 mRNA expression increased & $* * 2.8 \mathrm{mg} / \mathrm{L}$ & $4-28 \mathrm{hpf}$ & $28 \mathrm{hpf}$ & [42] \\
\hline apex 1 mRNA expression increased & $* * 7.0 \mathrm{mg} / \mathrm{L}$ & $4-28 \mathrm{hpf}$ & $28 \mathrm{hpf}$ & [42] \\
\hline parp 1 mRNA expression increased & $* * 2.8 \mathrm{mg} / \mathrm{L}$ & $4-28 \mathrm{hpf}$ & $28 \mathrm{hpf}$ & [42] \\
\hline$x r c c 1$ mRNA expression increased & $* * 7.0 \mathrm{mg} / \mathrm{L}$ & $4-28 \mathrm{hpf}$ & $28 \mathrm{hpf}$ & [42] \\
\hline lig3 mRNA expression increased & $* * 2.8 \mathrm{mg} / \mathrm{L}$ & $4-28 \mathrm{hpf}$ & $28 \mathrm{hpf}$ & [42] \\
\hline ung mRNA expression increased & $* * 2.8 \mathrm{mg} / \mathrm{L}$ & $4-28 \mathrm{hpf}$ & $28 \mathrm{hpf}$ & [42] \\
\hline pcna mRNA expression increased & $* * 2.8 \mathrm{mg} / \mathrm{L}$ & $4-28 \mathrm{hpf}$ & $28 \mathrm{hpf}$ & [42] \\
\hline polb mRNA expression decreased & $* * 7.0 \mathrm{mg} / \mathrm{L}$ & $4-28 \mathrm{hpf}$ & $28 \mathrm{hpf}$ & [42] \\
\hline pold mRNA expression decreased & $* * 2.8 \mathrm{mg} / \mathrm{L}$ & $4-28 \mathrm{hpf}$ & $28 \mathrm{hpf}$ & [42] \\
\hline fen 1 mRNA expression increased & $* * 7.0 \mathrm{mg} / \mathrm{L}$ & $4-28 \mathrm{hpf}$ & $28 \mathrm{hpf}$ & [42] \\
\hline lig1 mRNA expression increased & $* * 14 \mathrm{mg} / \mathrm{L}$ & $4-28 \mathrm{hpf}$ & $28 \mathrm{hpf}$ & [42] \\
\hline
\end{tabular}

\subsection{Transgenerational Effect}

Kamstra et al. investigated the transgenerational effect of MEHP exposures among three generations of zebrafish larvae (denoted as F0, F1 and F2), with only the F0 generation having been exposed to $30 \mu \mathrm{M}$ of MEHP from 0 to $6 \mathrm{dpf}$ [50]. Body length differences were 
reported in F0 larvae at 3 and $6 \mathrm{dpf}$, which had been exposed to MEHP, while no effect was reported in F1 and F2 larvae [50]. Altered dnmt gene expressions (dnmt1, dnmt3aa, dnmt3ab, $d n m t 3 b b .1, d n m t 3 b b .2)$ and decreased global hmC levels were reported in F0 larvae at $6 \mathrm{dpf}$. Furthermore, global demethylation in livers of F0 adult female zebrafish and reduction of global hmC levels in brain tissues of F0 adult male zebrafish were detected [50]. In the same study, MEHP exposure was found to lead to a significant increase in the average methylation at conserved non-genic elements in zebrafish (zfCNEs) when compared to the control [50]. The pathways involved in adipogenesis were enriched after MEHP exposures, which were suggested to link to a potential obesogenic effect of MHEP [50]. Transgenerational effects were further assessed through locus-specific methylation analysis by comparing differences of the methylation pattern among the three generations (F0 at $6 \mathrm{dpf}, \mathrm{F} 1$ at $6 \mathrm{dpf}, \mathrm{F} 2$ at $6 \mathrm{dpf}, \mathrm{F} 0$ at $15 \mathrm{dpf}$ and F0 adult sperm). Transgenerational effects were shown at the $c b f a 2 t 2$ locus and specific CpG sites [50]. Table 9 summarizes the transgenerational effect from acute exposure to MEHP on zebrafish embryos.

Table 9. Transgenerational effect from acute exposure to MEHP on zebrafish embryos. ${ }^{* *}$ The concentration was converted from $\mathrm{nM}$ or $\mu \mathrm{M}$ using the molar mass of MEHP $278.34 \mathrm{~g} / \mathrm{mol}$.

\begin{tabular}{|c|c|c|c|c|}
\hline Endpoint & Lowest Effective Dose & Exposure & Endpoint Time & References \\
\hline $\begin{array}{c}\text { dnmt gene expressions altered (dnmt1, } \\
\text { dnmt3aa, dnmt3ab, } \\
d n m t 3 b b .1, d n m t 3 b b .2)\end{array}$ & F0: $* * 8.4 \mathrm{mg} / \mathrm{L}$ & $\begin{array}{l}\text { F0: start at embryo } \\
\text { stage-6 dpf }\end{array}$ & F0 6 dpf & [50] \\
\hline global demethylation in liver & F0: ${ }^{* *} 8.4 \mathrm{mg} / \mathrm{L}$ & $\begin{array}{l}\text { F0: start at embryo } \\
\text { stage- } 6 \mathrm{dpf}\end{array}$ & F0 adult female & [50] \\
\hline global hmC level decreased & F0: ** $8.4 \mathrm{mg} / \mathrm{L}$ & $\begin{array}{l}\text { F0: start at embryo } \\
\text { stage- } 6 \mathrm{dpf}\end{array}$ & F0 $6 \mathrm{dpf}$ & [50] \\
\hline $\begin{array}{c}\text { global hmC level decreased in } \\
\text { brain tissue }\end{array}$ & F0: $* * 8.4 \mathrm{mg} / \mathrm{L}$ & $\begin{array}{l}\text { F0: start at embryo } \\
\text { stage- } 6 \mathrm{dpf}\end{array}$ & F0 adult male & [50] \\
\hline $\begin{array}{l}\text { average methylation increased } \\
\text { at zfCNEs }\end{array}$ & F0: $* * 8.4 \mathrm{mg} / \mathrm{L}$ & $\begin{array}{l}\text { F0: start at embryo } \\
\text { stage-6 dpf }\end{array}$ & F0 $6 \mathrm{dpf}$ & [50] \\
\hline adipogenesis pathway increased & F0: $* * 8.4 \mathrm{mg} / \mathrm{L}$ & $\begin{array}{l}\text { F0: start at embryo } \\
\text { stage- } 6 \mathrm{dpf}\end{array}$ & F0 $6 \mathrm{dpf}$ & [50] \\
\hline $\begin{array}{c}\text { transgenerational effect: DNA } \\
\text { methylation at } c b f a 2 t 2 \text { locus and } \\
\text { specific CpG sites among F0, F1 and } \\
\text { F2 generations }\end{array}$ & F0: ** $8.4 \mathrm{mg} / \mathrm{L}$ & $\begin{array}{l}\text { F0: start at embryo } \\
\text { stage-6 dpf }\end{array}$ & $\begin{array}{l}\text { F0 } 6 \text { dpf, F1 } 6 \text { dpf, F2 } \\
6 \text { dpf, F0 } 15 \text { dpf and } \\
\text { F0 adult sperm }\end{array}$ & [50] \\
\hline
\end{tabular}

\subsection{Endocrine Disruption}

DEHP was reported to cause endocrine disruptions in zebrafish embryos $[38,47,48,55,59,60]$. Jia et al. demonstrated that DEHP exposures disrupted homeostasis of thyroid hormones (THs) and altered expression of critical genes related to hypothalamus-pituitary-thyroid (HPT) axis in the zebrafish [59]. In that study, zebrafish embryos were exposed to five concentrations of DEHP, namely, 0, 40, 100, 200 and $400 \mu \mathrm{g} / \mathrm{L}$ from 2 to $168 \mathrm{hpf}$. The results revealed that whole-body thyroxinem (T4) and triiodothyronine (T3) were significantly increased after exposure to the highest tested concentration of DEHP, which subsequently led to disruption of homeostatic balance of the thyroid hormone [59]. The authors further indicated that DEHP changed the expression of thyroid stimulating hormone $(t s h \beta)$, corticotrophin releasing hormone $(\mathrm{crh})$, uridine diphosphate glucuronosyl transferase (ugt1ab), iodothyronine deiodinase (dio2), transthyretin $(\mathrm{ttr})$ and NK2 homeobox 1 ( $n k x 2.1)$ involved in thyroid development and thyroglobulin $(t g)$ involved in thyroid synthesis [59]. Upregulation of $\operatorname{tsh} \beta$ and $c r h$ due to DEHP exposures were also observed in a dose dependent manner [59].

In a separate study, $50 \mu \mathrm{g} / \mathrm{L}$ of DEHP exposure was found to have significantly altered the expression of transcripts or proteins related to endocrine responses, including T3, T4, $17 \beta$ estradiol and estrogen receptor alpha (ER $\alpha)$ [48]. Hamid et al. revealed that DEHP could perturb the hypothalamic-pituitary-gonadal (HPG) axis in zebrafish embryos [38], where the HPG axis was proved to be essential for normal function of the reproductive 
system in fish [61]. Significant upregulations of expressions in HPG-axis-pathway-related genes including $e r \alpha$, estrogen receptor beta (er $\beta)$, androgen receptor (ar), cytochrome P450 aromatase (cyp19a) and vitellogenin (vtg) in zebrafish embryos were observed upon exposures to $50 \mu \mathrm{g} / \mathrm{L}$ of DEHP. The results showed that DEHP altered er $\alpha$, er $\beta$ expressions in a concentration dependent manner [38]. In a separate study, An et al. also reported significant upregulation of $e r \alpha$ and $v t g$ expressions in embryos upon exposures to $0.1 \mathrm{mg} / \mathrm{L}$ of DEHP; however, no significant differences were found in $\operatorname{er} \beta$ expressions [60]. The study also found increased expression of cyp $19 b$ in DEHP-exposed zebrafish embryos [60]. In relation, Lee et al. reported that the transcript level of HPG-axis-related genes (vtg1, era, cyp19a1b) were significantly altered upon DEHP exposures [47]. In another study, Junaid et al. studied cancer cell migration in DEHP-exposed zebrafish through injection of labelled breast cancer cells into $72 \mathrm{hpf}$ larvae followed by two different levels of DEHP exposures (400 and $1600 \mu \mathrm{g} / \mathrm{L})$ for $6 \mathrm{~h}$ [55]. The distances traveled by cancer cells in zebrafish were determined through the fluorescence sites and intensities. DEHP-induced cancer-cell migration was confirmed through changes in the fluorescence distribution in the yolk, gut and tail in two DEHP-dosed groups when compared to the control group, while the total fluorescence intensity was unchanged [55].

MEHP was also found to cause endocrine disruptions in zebrafish embryos [62-65]. Zhai et al. reported MEHP exposures elevated T3 and reduced T4 contents in zebrafish embryos [62]. The results linked the genes involved in thyroid hormone metabolism (iodothyronine deiodinase (Dio2), UDP-glucuronosyltransferases (UGT1ab)) to T4 content reduction. The genes related to thyroid development (Nkx2.1, Paired Box 8 (Pax8)), thyroid hormone synthesis (TSH $\beta$, sodium/iodide symporter (NIS) and TG) and TH transport (transthyretin, TTR) were significantly altered after MEHP exposures [62]. In a separate study, MEHP was reported to disrupt glutahione (GSH) homeostasis in zebrafish embryos [63]. GSH played a critical role in embryonic development and organogenesis, which were revealed through monochlorobimane (MCB) staining [63]. In this study, the zebrafish were exposed to $200 \mu \mathrm{g} / \mathrm{L}$ MEHP from $3 \mathrm{hpf}$ to either 48 or $72 \mathrm{hpf}$. Reductions in MCB fluorescence intensities in the body, heart, brain ventricle and somite 12 were found at both time points, while more serious disruptions were observed in $48 \mathrm{hpf}$ embryos. These results confirmed that MEHP exposures disrupted GSH utilization in specific tissues during embryo development [63]. In separate studies, MEHP was found to disrupt pancreatic organogenesis in zebrafish embryos $[64,65]$. The endocrine tissue within the pancreas was called islet of Langerhans, which contained $\alpha$-cells and $\beta$-cells responsible for secreting glucagon and insulin, respectively. Sant et al. studied the effect of exposures to $0.7 \mu \mathrm{M}$ MEHP on the pancreatic islet development in transgenic zebrafish $\mathrm{Tg}$ (ins:GFP) embryos at $48 \mathrm{hpf}$ [65], and demonstrated that MEHP produced hypomorphic islets with evidence of reduction in $\beta$-cell cluster area [65]. In relation, Jacob et al. confirmed that exposures to $200 \mu \mathrm{g} / \mathrm{L}$ MEHP reduced $\beta$-cell as well as $\alpha$-cell cluster area in transgenic zebrafish $T g($ ins:GFP) and $T g(g c g a: G F P)$, respectively. Both these studies confirmed MEHP exposures increased the frequency of pancreatic islet morphology variants such as fragmented and ectopic islets, relative to the control $[64,65]$. Jacob et al. also reported that MEHP exposures altered expression of genes related to endocrine hormone (preproinsulin a (insa), somatostatin 2 (sst2)), exocrine (pancreasspecific transcription factor 1a, ptf1a) and glutathione (GSH) (glutathione disulfide reductase (gsr), glutathione S-transferase pi 1 (gstp)) in wildtype zebrafish embryos. Changes in the pancreatic structure were also observed in MEHP-exposed wildtype and mutant zebrafish embryos [64]. Table 10 summarizes the endocrine disruption from acute exposures to DEHP or MEHP in zebrafish embryos. 
Table 10. Endocrine disruption from acute exposures to (a) DEHP and (b) MEHP in zebrafish embryos. ${ }^{*}$ The concentration was converted from $\mathrm{nM}$ or $\mu \mathrm{M}$ using the molar mass of MEHP $278.34 \mathrm{~g} / \mathrm{mol}$.

\begin{tabular}{|c|c|c|c|c|}
\hline Endpoint & Lowest Effective Dose & Exposure & Endpoint Time & References \\
\hline triiodothyronine (T3) level increased & $400 \mu \mathrm{g} / \mathrm{L}$ & $2-168 \mathrm{hpf}$ & $168 \mathrm{hpf}$ & [59] \\
\hline triiodothyronine (T3) level increased & $250 \mu \mathrm{g} / \mathrm{L}$ & $2-96 \mathrm{hpf}$ & $96 \mathrm{hpf}$ & [48] \\
\hline thyroxinem (T4) level increased & $400 \mu \mathrm{g} / \mathrm{L}$ & $2-168 \mathrm{hpf}$ & $168 \mathrm{hpf}$ & [59] \\
\hline thyroxinem (T4) level increased & $250 \mu \mathrm{g} / \mathrm{L}$ & $2-96 \mathrm{hpf}$ & $96 \mathrm{hpf}$ & [48] \\
\hline $\begin{array}{l}\text { estrogen receptor alpha }(e r \alpha) \\
\text { mRNA increased }\end{array}$ & $50 \mu \mathrm{g} / \mathrm{L}$ & $3-96 \mathrm{hpf}$ & $96 \mathrm{hpf}$ & [38] \\
\hline $\begin{array}{l}\text { estrogen receptor alpha }(e r \alpha) \\
m R N A \text { increased }\end{array}$ & $250 \mu \mathrm{g} / \mathrm{L}$ & $2-96 \mathrm{hpf}$ & $96 \mathrm{hpf}$ & [48] \\
\hline $\begin{array}{c}\text { estrogen receptor alpha }(E R \alpha) \text { gene } \\
\text { expression increased }\end{array}$ & $100 \mu \mathrm{g} / \mathrm{L}$ & $\begin{array}{l}\text { start at embryo } \\
\text { stage-168 hpf }\end{array}$ & $168 \mathrm{hpf}$ & {$[60]$} \\
\hline $\begin{array}{c}\text { estrogen receptor alpha }(E R \alpha) \text { protein } \\
\text { level increased }\end{array}$ & $250 \mu \mathrm{g} / \mathrm{L}$ & $2-96 \mathrm{hpf}$ & $96 \mathrm{hpf}$ & [48] \\
\hline $\begin{array}{c}\text { estrogen receptor alpha }(e r \alpha) \text { transcript } \\
\text { level decreased }\end{array}$ & $10 \mu \mathrm{g} / \mathrm{L}$ & $6-168 \mathrm{hpf}$ & $168 \mathrm{hpf}$ & [47] \\
\hline $\begin{array}{c}\text { estrogen receptor beta }(\operatorname{er} \beta) \\
\text { mRNA increased }\end{array}$ & $50 \mu \mathrm{g} / \mathrm{L}$ & 3-96 hpf & $96 \mathrm{hpf}$ & [38] \\
\hline $\begin{array}{l}\text { cytochrome P450 aromatase (cyp } 19 a) \\
\text { expression increased }\end{array}$ & $25 \mu \mathrm{g} / \mathrm{L}$ & $3-96 \mathrm{hpf}$ & $96 \mathrm{hpf}$ & {$[38]$} \\
\hline $\begin{array}{c}\text { cytochrome P450 aromatase (Cyp19b) gene } \\
\text { expression increased }\end{array}$ & $100 \mu \mathrm{g} / \mathrm{L}$ & $\begin{array}{l}\text { start at embryo } \\
\text { stage-168 hpf }\end{array}$ & $168 \mathrm{hpf}$ & {$[60]$} \\
\hline $\begin{array}{c}\text { cytochrome P450 aromatase (cyp19a1b) } \\
\text { transcript level increased }\end{array}$ & $10 \mu \mathrm{g} / \mathrm{L}$ & 6-168 hpf & $168 \mathrm{hpf}$ & [47] \\
\hline $\begin{array}{l}\text { vitellogenin }(v t g) \text { mRNA } \\
\text { expression increased }\end{array}$ & $25 \mu \mathrm{g} / \mathrm{L}$ & $3-96 \mathrm{hpf}$ & $96 \mathrm{hpf}$ & [38] \\
\hline $\begin{array}{l}\text { vitellogenin }(\mathrm{Vtg}) \text { gene } \\
\text { expression increased }\end{array}$ & $100 \mu \mathrm{g} / \mathrm{L}$ & $\begin{array}{l}\text { start at embryo } \\
\text { stage-168 hpf }\end{array}$ & $168 \mathrm{hpf}$ & {$[60]$} \\
\hline $\begin{array}{l}\text { vitellogenin (vtg1) transcript } \\
\text { level increased }\end{array}$ & $100 \mu \mathrm{g} / \mathrm{L}$ & $6-168 \mathrm{hpf}$ & $168 \mathrm{hpf}$ & [47] \\
\hline $\begin{array}{l}\text { thyroid stimulating hormone }(\operatorname{tsh} \beta) \\
\text { mRNA expression increased }\end{array}$ & $100 \mu \mathrm{g} / \mathrm{L}$ & $2-168 \mathrm{hpf}$ & $168 \mathrm{hpf}$ & [59] \\
\hline $\begin{array}{l}\text { corticotrophin releasing hormone }(\mathrm{crh}) \\
\text { mRNA expression increased }\end{array}$ & $200 \mu \mathrm{g} / \mathrm{L}$ & $2-168 \mathrm{hpf}$ & $168 \mathrm{hpf}$ & [59] \\
\hline $\begin{array}{c}\text { NK2 homeobox } 1 \text { ( } n k x 2.1) \text { mRNA } \\
\text { expression increased }\end{array}$ & $200 \mu \mathrm{g} / \mathrm{L}$ & $2-168 \mathrm{hpf}$ & $168 \mathrm{hpf}$ & [59] \\
\hline $\begin{array}{l}\text { thyroglobulin }(t g) \text { mRNA } \\
\text { expression increased }\end{array}$ & $400 \mu \mathrm{g} / \mathrm{L}$ & $2-168 \mathrm{hpf}$ & $168 \mathrm{hpf}$ & [59] \\
\hline $\begin{array}{l}\text { uridinediphosphate-glucuronosyl- } \\
\text { transferase (ugtlab) } \\
\text { mRNA expression decreased }\end{array}$ & $200 \mu \mathrm{g} / \mathrm{L}$ & $2-168 \mathrm{hpf}$ & $168 \mathrm{hpf}$ & [59] \\
\hline $\begin{array}{l}\text { iodothyronine deiodinase (dio2) mRNA } \\
\text { expression increased }\end{array}$ & $400 \mu \mathrm{g} / \mathrm{L}$ & $2-168 \mathrm{hpf}$ & $168 \mathrm{hpf}$ & [59] \\
\hline $\begin{array}{l}\text { transthyretin }(t t r) \text { mRNA } \\
\text { expression increased }\end{array}$ & $200 \mu \mathrm{g} / \mathrm{L}$ & $2-168 \mathrm{hpf}$ & $168 \mathrm{hpf}$ & [59] \\
\hline $\begin{array}{l}\text { androgen receptor (ar) mRNA } \\
\text { expression increased }\end{array}$ & $50 \mu \mathrm{g} / \mathrm{L}$ & 3-96 hpf & $96 \mathrm{hpf}$ & [38] \\
\hline $17 \beta$ estradiol level increased & $250 \mu \mathrm{g} / \mathrm{L}$ & $2-96 \mathrm{hpf}$ & $96 \mathrm{hpf}$ & [48] \\
\hline $\begin{array}{l}\text { cancer cell migration (from yolk to gut } \\
\text { and tail) }\end{array}$ & $400 \mu \mathrm{g} / \mathrm{L}$ & $72-78 \mathrm{hpf}$ & $78 \mathrm{hpf}$ & [55] \\
\hline
\end{tabular}


Table 10. Cont.

\begin{tabular}{|c|c|c|c|c|}
\hline \multicolumn{5}{|l|}{ (b) MEHP } \\
\hline Endpoint & Lowest Effective Dose & Exposure & Endpoint Time & References \\
\hline triiodothyronine (T3) level increased & $200 \mu \mathrm{g} / \mathrm{L}$ & $2-168 \mathrm{hpf}$ & $168 \mathrm{hpf}$ & {$[62]$} \\
\hline thyroxinem (T4) level decreased & $200 \mu \mathrm{g} / \mathrm{L}$ & $2-168 \mathrm{hpf}$ & $168 \mathrm{hpf}$ & [62] \\
\hline $\begin{array}{l}\text { thyroid stimulating hormone }(\mathrm{TSH} \beta) \\
\text { transcription increased }\end{array}$ & $40 \mu \mathrm{g} / \mathrm{L}$ & 2-168 hpf & $168 \mathrm{hpf}$ & [62] \\
\hline $\begin{array}{l}\text { NK2 Homeobox } 1 \text { (Nkx2.1) } \\
\text { transcription increased }\end{array}$ & $8 \mu \mathrm{g} / \mathrm{L}$ & $2-168 \mathrm{hpf}$ & $168 \mathrm{hpf}$ & [62] \\
\hline thyroglobulin $(T G)$ transcription increased & $200 \mu \mathrm{g} / \mathrm{L}$ & $2-168 \mathrm{hpf}$ & $168 \mathrm{hpf}$ & {$[62]$} \\
\hline $\begin{array}{l}\text { UDP-glucuronosyltransferases (UGT1ab) } \\
\text { transcription increased }\end{array}$ & $40 \mu \mathrm{g} / \mathrm{L}$ & $2-168 \mathrm{hpf}$ & $168 \mathrm{hpf}$ & {$[62]$} \\
\hline $\begin{array}{l}\text { iodothyronine deiodinase (Dio1) } \\
\text { transcription increased }\end{array}$ & $8 \mu \mathrm{g} / \mathrm{L}$ & $2-168 \mathrm{hpf}$ & $168 \mathrm{hpf}$ & {$[62]$} \\
\hline $\begin{array}{l}\text { iodothyronine deiodinase (Dio2) } \\
\text { transcription increased }\end{array}$ & $40 \mu \mathrm{g} / \mathrm{L}$ & $2-168 \mathrm{hpf}$ & $168 \mathrm{hpf}$ & {$[62]$} \\
\hline $\begin{array}{l}\text { transthyretin }(T T R) \\
\text { transcription decreased }\end{array}$ & $200 \mu \mathrm{g} / \mathrm{L}$ & $2-168 \mathrm{hpf}$ & $168 \mathrm{hpf}$ & {$[62]$} \\
\hline $\begin{array}{l}\text { paired box } 8(\operatorname{Pax} 8) \\
\text { transcription increased }\end{array}$ & $8 \mu \mathrm{g} / \mathrm{L}$ & $2-168 \mathrm{hpf}$ & $168 \mathrm{hpf}$ & {$[62]$} \\
\hline $\begin{array}{l}\text { sodium/iodide symporter (NIS) } \\
\text { transcription increased }\end{array}$ & $40 \mu \mathrm{g} / \mathrm{L}$ & $2-168 \mathrm{hpf}$ & $168 \mathrm{hpf}$ & [62] \\
\hline $\begin{array}{l}\text { GSH disruption in body, heart, brain } \\
\text { ventricle and somite } 12(\mathrm{MCB} \\
\text { fluorescence decreased) }\end{array}$ & $200 \mu \mathrm{g} / \mathrm{L}$ & $3-48 / 72 \mathrm{hpf}$ & $48 / 72 \mathrm{hpf}$ & {$[63]$} \\
\hline $\begin{array}{c}\text { hypomorphic islets ( } \beta \text {-cell cluster area } \\
\text { decreased)(Tg (ins:GFP)) }\end{array}$ & ** $195 \mu \mathrm{g} / \mathrm{L}$ & $3-48 \mathrm{hpf}$ & $48 \mathrm{hpf}$ & {$[65]$} \\
\hline $\begin{array}{c}\text { pancreatic islet variants and } \\
\text { defects decreased }\end{array}$ & ** $195 \mu \mathrm{g} / \mathrm{L}$ & $3-48 \mathrm{hpf}$ & $48 \mathrm{hpf}$ & {$[65]$} \\
\hline $\begin{array}{c}\text { hypomorphic islets ( } \beta \text {-cell cluster area } \\
\text { decreased })(\operatorname{Tg} \text { (ins:GFP)) }\end{array}$ & $200 \mu \mathrm{g} / \mathrm{L}$ & $3-48 / 72 / 96 / 168 \mathrm{hpf}$ & $48 / 72 / 96 / 168 \mathrm{hpf}$ & {$[64]$} \\
\hline $\begin{array}{c}\text { hypomorphic islets ( } \alpha \text {-cell cluster area } \\
\text { decreased) (Tg (gcga:GFP)) }\end{array}$ & $200 \mu \mathrm{g} / \mathrm{L}$ & $3-48 / 72 / 96 / 168 \mathrm{hpf}$ & $48 / 72 / 96 / 168 \mathrm{hpf}$ & {$[64]$} \\
\hline $\begin{array}{c}\text { frequency of pancreatic islet morphology } \\
\text { variants increased }\end{array}$ & $200 \mu \mathrm{g} / \mathrm{L}$ & $3-48 / 72 / 96 / 168 \mathrm{hpf}$ & $48 / 72 / 96 / 168 \mathrm{hpf}$ & {$[64]$} \\
\hline $\begin{array}{c}\text { pancreatic structure altered in wt } \\
\text { zebrafish embryo }\end{array}$ & $200 \mu \mathrm{g} / \mathrm{L}$ & $3-48 / 72 / 96 \mathrm{hpf}$ & $48 / 72 / 96 \mathrm{hpf}$ & {$[64]$} \\
\hline $\begin{array}{c}\text { pancreatic structure altered in } \mathrm{m} \\
\text { zebrafish embryo }\end{array}$ & $200 \mu \mathrm{g} / \mathrm{L}$ & $3-48 / 72 / 96 \mathrm{hpf}$ & $48 / 72 / 96 \mathrm{hpf}$ & {$[64]$} \\
\hline $\begin{array}{l}\text { preproinsulin a (insa) } \\
\text { expression decreased }\end{array}$ & $200 \mu \mathrm{g} / \mathrm{L}$ & 3-96 hpf & $96 \mathrm{hpf}$ & {$[64]$} \\
\hline somatostatin 2 (sst2) expression decreased & $200 \mu \mathrm{g} / \mathrm{L}$ & 3-96 hpf & $96 \mathrm{hpf}$ & {$[64]$} \\
\hline $\begin{array}{l}\text { pancreasspecifictranscription factor } 1 \mathrm{a} \\
(p t f 1 a) \text { expression decreased }\end{array}$ & $200 \mu \mathrm{g} / \mathrm{L}$ & 3-96 hpf & $96 \mathrm{hpf}$ & {$[64]$} \\
\hline $\begin{array}{l}\text { glutathione-disulfide reductase }(g s r) \\
\text { expression increased }\end{array}$ & $200 \mu \mathrm{g} / \mathrm{L}$ & 3-96 hpf & $96 \mathrm{hpf}$ & {$[64]$} \\
\hline $\begin{array}{c}\text { glutathione S-transferase pi } 1 \text { (gstp) } \\
\text { expression decreased }\end{array}$ & $200 \mu \mathrm{g} / \mathrm{L}$ & $3-96 \mathrm{hpf}$ & $96 \mathrm{hpf}$ & [64] \\
\hline
\end{tabular}

\section{Effects from Chronic Exposure}

Chronic toxicities on the development, reproduction and intestines in zebrafish were assessed after exposures to DEHP from the embryo to adult stage [39,66]. After being exposed for 1 month to $0.5 \mu \mathrm{g} / \mathrm{L}$ DEHP, the mortality rate of hatchlings was reported as $60.57 \%$, compared to the rate of $11.11 \%$ observed for the control group [39]. Muhammad et al. assessed developmental and reproductive toxicities in zebrafish upon 6-month exposures to $0.5 \mu \mathrm{g} / \mathrm{L}$ DEHP through the survived hatchlings at 1 month. Both the body lengths and weights of female and male zebrafish adults were significantly reduced [39]. After 6-month DEHP exposures, the gonad somatic index (GSI) was reduced for both 
female and male zebrafish adults, which implied interruption of gonad development. Breeding disruption in zebrafish adults was also reported in terms of decreasing egg production and increasing non-fertilization rate [39]. Muhammad et al. further applied histological examination to investigate the development of testis and ovary in zebrafish treated with $0.5 \mu \mathrm{g} / \mathrm{L}$ of DEHP. The testes and ovaries of zebrafish in the control group were confirmed normal. In the DEHP-dosed male group, well-developed testes were observed while disruption of tubules as well as reduction in spermatogonia and spermatocyte were found [39]. In the DEHP-dosed female group, undeveloped ovaries were identified from the peri-nucleolar oocytes and early cortical alveolar oocytes [39]. These results showed that long-term DEHP exposures posed toxicity on growth, reproduction and fecundity in zebrafish. In a separate study, a gender-based zebrafish study was conducted to investigate the effects of exposures to environmental concentrations $(0,10,33,100 \mu \mathrm{g} / \mathrm{L})$ of DEHP in embryos to 3.5-month adults [66]. Increased body lengths and weights as well as altered intestinal microbiota and bacteria were reported in both male and female zebrafish following DEHP exposures [66]. Increased conditional factors (K) were found in female zebrafish treated with $10 \mu \mathrm{g} / \mathrm{L}$ of DEHP and in male zebrafish treated with $33 \mu \mathrm{g} / \mathrm{L}$ of DEHP. Reduction in villus width and goblet cells per villus in male and reduction of tunica muscularis thickness in female were also reported in DEHP-treated zebrafish via histological analysis [66]. Besides, in the intestines of DEHP-treated zebrafish, the content of energy metabolites (TG, PY, FA, Glu) and the expression of key genes involved in immune response $(t l r-5, i l-1 \beta, n f-k b, i l-8)$ were altered [66]. Based on these results, the study suggested that DEHP could induce obesity as evidenced from altered developmental indices, intestinal microbial community and metabolic homeostasis [66]. Table 11 summarizes the effects from chronic exposure to DEHP on zebrafish embryos.

Table 11. Effects from chronic exposure to DEHP on zebrafish embryos.

\begin{tabular}{|c|c|c|c|c|}
\hline Endpoint & Lowest Effective Dose & Exposure & Endpoint Time & References \\
\hline mortality rate increased & $0.5 \mu \mathrm{g} / \mathrm{L}$ & $27 \mathrm{hpf}-1$ month & 1 month & [39] \\
\hline body length increased (male) & $33 \mu \mathrm{g} / \mathrm{L}$ & $\begin{array}{l}\text { start at embryo } \\
\text { stage-3.5 month }\end{array}$ & 3.5 month & [66] \\
\hline body length decreased (male) & $0.5 \mu \mathrm{g} / \mathrm{L}$ & $27 \mathrm{hpf}-6$ month & 6 month & [39] \\
\hline body length increased (female) & $10 \mu \mathrm{g} / \mathrm{L}$ & $\begin{array}{l}\text { start at embryo } \\
\text { stage-3.5 month }\end{array}$ & 3.5 month & [66] \\
\hline body length decreased (female) & $0.5 \mu \mathrm{g} / \mathrm{L}$ & $27 \mathrm{hpf}-6$ month & 6 month & [39] \\
\hline body weight increased (male) & $10 \mu \mathrm{g} / \mathrm{L}$ & $\begin{array}{l}\text { start at embryo } \\
\text { stage-3.5 month }\end{array}$ & 3.5 month & {$[66]$} \\
\hline body weight decreased (male) & $0.5 \mu \mathrm{g} / \mathrm{L}$ & $27 \mathrm{hpf}-6$ month & 6 month & [39] \\
\hline body weight increased (female) & $10 \mu \mathrm{g} / \mathrm{L}$ & $\begin{array}{l}\text { start at embryo } \\
\text { stage-3.5 month }\end{array}$ & 3.5 month & [66] \\
\hline body weight decreased (female) & $0.5 \mu \mathrm{g} / \mathrm{L}$ & $27 \mathrm{hpf}-6$ month & 6 month & [39] \\
\hline intestinal microbiota alteration (female) & $100 \mu \mathrm{g} / \mathrm{L}$ & $\begin{array}{l}\text { start at embryo } \\
\text { stage-3.5 month }\end{array}$ & 3.5 month & {$[66]$} \\
\hline intestinal microbiota alteration (male) & $100 \mu \mathrm{g} / \mathrm{L}$ & $\begin{array}{l}\text { start at embryo } \\
\text { stage-3.5 month }\end{array}$ & 3.5 month & {$[66]$} \\
\hline intestinal bacteria alteration (female) & $100 \mu \mathrm{g} / \mathrm{L}$ & $\begin{array}{l}\text { start at embryo } \\
\text { stage-3.5 month }\end{array}$ & 3.5 month & {$[66]$} \\
\hline intestinal bacteria alteration (male) & $100 \mu \mathrm{g} / \mathrm{L}$ & $\begin{array}{l}\text { start at embryo } \\
\text { stage- }-3.5 \text { month }\end{array}$ & 3.5 month & {$[66]$} \\
\hline villus width decreased (male) & $100 \mu \mathrm{g} / \mathrm{L}$ & $\begin{array}{l}\text { start at embryo } \\
\text { stage-3.5 month }\end{array}$ & 3.5 month & [66] \\
\hline $\begin{array}{l}\text { tunica muscularis thickness } \\
\text { decreased (female) }\end{array}$ & $100 \mu \mathrm{g} / \mathrm{L}$ & $\begin{array}{l}\text { start at embryo } \\
\text { stage-3.5 month }\end{array}$ & 3.5 month & {$[66]$} \\
\hline goblet cells per villus decreased (female) & $100 \mu \mathrm{g} / \mathrm{L}$ & $\begin{array}{l}\text { start at embryo } \\
\text { stage-3.5 month }\end{array}$ & 3.5 month & [66] \\
\hline
\end{tabular}


Table 11. Cont.

\begin{tabular}{|c|c|c|c|c|}
\hline Endpoint & Lowest Effective Dose & Exposure & Endpoint Time & References \\
\hline tlr-5 mRNA expression decreased (female) & $100 \mu \mathrm{g} / \mathrm{L}$ & $\begin{array}{l}\text { start at embryo } \\
\text { stage-3.5 month }\end{array}$ & 3.5 month & [66] \\
\hline il-1 $\beta$ mRNA expression decreased (female) & $10 \mu \mathrm{g} / \mathrm{L}$ & $\begin{array}{l}\text { start at embryo } \\
\text { stage-3.5 month }\end{array}$ & 3.5 month & [66] \\
\hline il-8 mRNA expression increased (male) & $10 \mu \mathrm{g} / \mathrm{L}$ & $\begin{array}{l}\text { start at embryo } \\
\text { stage-3.5 month }\end{array}$ & 3.5 month & [66] \\
\hline il-8 mRNA expression increased (female) & $10 \mu \mathrm{g} / \mathrm{L}$ & $\begin{array}{l}\text { start at embryo } \\
\text { stage-3.5 month }\end{array}$ & 3.5 month & {$[66]$} \\
\hline TG content increased (male) & $33 \mu \mathrm{g} / \mathrm{L}$ & $\begin{array}{l}\text { start at embryo } \\
\text { stage-3.5 month }\end{array}$ & 3.5 month & {$[66]$} \\
\hline TG content increased (female) & $10 \mu \mathrm{g} / \mathrm{L}$ & $\begin{array}{l}\text { start at embryo } \\
\text { stage-3.5 month }\end{array}$ & 3.5 month & [66] \\
\hline PY content increased (male) & $10 \mu \mathrm{g} / \mathrm{L}$ & $\begin{array}{l}\text { start at embryo } \\
\text { stage }-3.5 \text { month }\end{array}$ & 3.5 month & {$[66]$} \\
\hline PY content increased (female) & $33 \mu \mathrm{g} / \mathrm{L}$ & $\begin{array}{l}\text { start at embryo } \\
\text { stage-3.5 month }\end{array}$ & 3.5 month & {$[66]$} \\
\hline FA content increased (male) & $10 \mu \mathrm{g} / \mathrm{L}$ & $\begin{array}{l}\text { start at embryo } \\
\text { stage-3.5 month }\end{array}$ & 3.5 month & [66] \\
\hline Glu content increased (female) & $10 \mu \mathrm{g} / \mathrm{L}$ & $\begin{array}{l}\text { start at embryo } \\
\text { stage-3.5 month }\end{array}$ & 3.5 month & [66] \\
\hline conditional factor increased (male) & $33 \mu \mathrm{g} / \mathrm{L}$ & $\begin{array}{l}\text { start at embryo } \\
\text { stage-3.5 month }\end{array}$ & 3.5 month & {$[66]$} \\
\hline conditional factor increased (female) & $10 \mu \mathrm{g} / \mathrm{L}$ & $\begin{array}{l}\text { start at embryo } \\
\text { stage-3.5 month }\end{array}$ & 3.5 month & [66] \\
\hline Gonad somatic index (GSI) decreased (male) & $0.5 \mu \mathrm{g} / \mathrm{L}$ & $27 \mathrm{hpf}-6$ month & 6 month & [39] \\
\hline $\begin{array}{c}\text { Gonad somatic index (GSI) } \\
\text { decreased (female) }\end{array}$ & $0.5 \mu \mathrm{g} / \mathrm{L}$ & $27 \mathrm{hpf}-6$ month & 6 month & [39] \\
\hline egg production decreased & $0.5 \mu \mathrm{g} / \mathrm{L}$ & $27 \mathrm{hpf}-6$ month & 6 month & [39] \\
\hline non-fertilization rate increased & $0.5 \mu \mathrm{g} / \mathrm{L}$ & $27 \mathrm{hpf}-6$ month & 6 month & [39] \\
\hline $\begin{array}{c}\text { spermatogonia and spermatocyte } \\
\text { decreased (male) }\end{array}$ & $0.5 \mu \mathrm{g} / \mathrm{L}$ & $27 \mathrm{hpf}-6$ month & 6 month & [39] \\
\hline tubules distruption (male) & $0.5 \mu \mathrm{g} / \mathrm{L}$ & $27 \mathrm{hpf}-6$ month & 6 month & [39] \\
\hline ovary development inhibition (female) & $0.5 \mu \mathrm{g} / \mathrm{L}$ & $27 \mathrm{hpf}-6$ month & 6 month & [39] \\
\hline $\begin{array}{c}\text { number of vitellogenic oocytes } \\
\text { decreased (female) }\end{array}$ & $0.5 \mu \mathrm{g} / \mathrm{L}$ & $27 \mathrm{hpf}-6$ month & 6 month & [39] \\
\hline
\end{tabular}

\section{Summary}

DEHP is the most extensively applied phthalate accounting for nearly $50 \%$ of global phthalate consumption and has been associated with various adverse health effects. Health concerns have been raised regarding DEHP exposures and in consequence, risk assessment on DEHP exposures has become a required procedure. In the present review, we focused on the toxicities induced by acute or chronic DEHP exposures on zebrafish embryos with the exposure window, which started from the embryo stage. Apart from the parent phthalate DEHP, its major metabolite MEHP could also be detected in the human body and related to different adverse health effects, which was mentioned in Section 1. Both the parent phthalate, DEHP, and its major metabolite, MEHP, could induce various adverse developmental effects on zebrafish embryos upon acute or chronic exposures, which were summarized in Tables 1-11, with the lowest effective dose, exposure widow and time point for assessing each of the biological endpoints in order to facilitate the comparison between the outcomes from different studies.

The linkage between various developmental and teratogenic toxicities and the underlying mechanisms requires further investigation. For comparing the toxicities of DEHP and MEHP exposures, a parallel experiment showed that the lowest effective doses of DEHP and MEHP were different to induce the reduction of survival rate, hatching rate and body length as well as an increase in deformity rate [42]. Besides, the data from a zebrafish 
developmental screening showed that only the active metabolite MEHP was toxic, while the parent DEHP tested negative in the concentration-response study [67]. More studies are required to investigate the lowest effective dose as well as mechanisms underlying different developmental effects of DEHP and MEHP, and to further reveal whether they pose the same toxic effects through the same mechanisms to living organisms.

As many key developmental signaling pathways and their regulations are conserved between zebrafish and mammals, the zebrafish model has been employed for investigating mammalian disease as well as developmental pathways on the molecular basis $[68,69]$. MEHP have been shown to induce hepatic toxicity [51], and DEHP have been reported to alter critical genes related to HPT axis and produce reproductive toxicity on zebrafish $[39,58]$. Since zebrafish develops relevant structures, e.g., liver for metabolic conversions [70] as well as the thyroid gland which is responsible for controlling development [71], it might facilitate assessment of toxicity in mammals. More comprehensive studies are required to provide better understanding on the mechanistic pathways of DEHP- and MEHP-induced toxic effects and to establish a correlation between zebrafish developmental toxicity and mammalian developmental toxicity that may facilitate further development on risk assessment.

Author Contributions: Conceptualization, W.S.K. and K.N.Y.; writing—original draft preparation, W.S.K. and K.N.Y.; writing — review and editing, W.S.K., V.A.L.R. and K.N.Y.; visualization, W.S.K. and K.N.Y.; supervision, K.N.Y. and V.A.L.R.; project administration, V.A.L.R.; funding acquisition, V.A.L.R. All authors have read and agreed to the published version of the manuscript.

Funding: This research was funded by the Innovation and Technology Fund from HKSAR (grant number UIM/371), and by the State Key Laboratory in Marine Pollution of the City University of Hong Kong (grant number IRF/0024).

Conflicts of Interest: The authors declare no conflict of interest. The funders had no role in the design of the study; in the collection, analyses, or interpretation of data; in the writing of the manuscript, or in the decision to publish the results.

\section{References}

1. Schettler, T. Human exposure to phthalates via consumer products. Int. J. Androl. 2006, 29, 134-139. [CrossRef]

2. Schug, T.T.; Janesick, A.; Blumberg, B.; Heindel, J.J. Endocrine disrupting chemicals and disease susceptibility. J. Steroid Biochem. Mol. Biol. 2011, 127, 204-215. [CrossRef]

3. Rahman, M.; Brazel, C.S. The plasticizer market: An assessment of traditional plasticizers and research trends to meet new challenges. Prog. Polym. Sci. 2004, 29, 1223-1248. [CrossRef]

4. Zhang, X.; Chen, Z. Observing Phthalate Leaching from Plasticized Polymer Films at the Molecular Level. Langmuir 2014, 30, 4933-4944. [CrossRef] [PubMed]

5. Alp, A.C.; Yerlikaya, P. Phthalate ester migration into food: Effect of packaging material and time. Eur. Food Res. Technol. 2020, 246, 425-435. [CrossRef]

6. Wang, Y.; Zhu, H.; Kannan, K. A Review of Biomonitoring of Phthalate Exposures. Toxics 2019, 7, 21. [CrossRef]

7. Marie, C.; Vendittelli, F.; Sauvant-Rochat, M.-P. Obstetrical Outcomes and Biomarkers to Assess Exposure to Phthalates: A Review. Environ. Int. 2015, 83, 116-136. [CrossRef]

8. Zarean, M.; Keikha, M.; Poursafa, P.; Khalighinejad, P.; Amin, M.; Kelishadi, R. A Systematic Review on the Adverse Health Effects of Di-2-Ethylhexyl Phthalate. Environ. Sci. Pollut. Res. 2016, 23, 24642-24693. [CrossRef]

9. International Agency for Research on Cancer (IARC). IARC Monographs on the Identification of Carcinogenic Hazards to Humans; International Agency for Research on Cancer: Lyon, France, 2013; Volume 101.

10. United States Environmental Protection Agency (US EPA). Priority Pollutant List; United States Environmental Protection Agency: Washington, DC, USA, 2014.

11. European Union (EU). Commission Regulation (EU) 2018/2005. Available online: https:/ / eur-lex.europa.eu/legal-content/EN/ TXT/PDF/?uri=CELEX:32018R2005\&from=EN (accessed on 15 March 2021).

12. United States Consumer Product Safety Commission (US CPSC). Consumer Product Safety Improvement Act of 2008; United States Consumer Product Safety Commission: Bethesda, MD, USA, 2008.

13. Canada Consumer Product Safety Act (CCPSA). Phthalate Regulations (SOR/2016-188). Available online: https:/ /laws-lois. justice.gc.ca/eng/regulations/SOR-2016-188/index.html (accessed on 15 March 2021). 
14. Högberg, J.; Hanberg, A.; Berglund, M.; Skerfving, S.; Remberger, M.; Calafat, A.M.; Filipsson, A.F.; Jansson, B.; Johansson, N.; Appelgren, M. Phthalate Diesters and Their Metabolites in Human Breast Milk, Blood or Serum, and Urine as Biomarkers of Exposure in Vulnerable Populations. Environ. Health Perspect. 2008, 116, 334-339. [CrossRef]

15. Silva, M.; Samandar, E.; Preaujr, J.; Reidy, J.; Needham, L.; Calafat, A. Quantification of 22 Phthalate Metabolites in Human Urine江. J. Chromatogr. B 2007, 860, 106-112. [CrossRef] [PubMed]

16. Guo, Y.; Alomirah, H.; Cho, H.-S.; Minh, T.B.; Mohd, M.A.; Nakata, H.; Kannan, K. Occurrence of Phthalate Metabolites in Human Urine from Several Asian Countries. Environ. Sci. Technol. 2011, 45, 3138-3144. [CrossRef] [PubMed]

17. Reddy, B.; Rozati, R.; Reddy, B.; Raman, N. General Gynaecology: Association of Phthalate Esters with Endometriosis in Indian Women. BJOG 2006, 113, 515-520. [CrossRef]

18. Joensen, U.N.; Frederiksen, H.; Jensen, M.B.; Lauritsen, M.P.; Olesen, I.A.; Lassen, T.H.; Andersson, A.-M.; Jørgensen, N. Phthalate Excretion Pattern and Testicular Function: A Study of 881 Healthy Danish Men. Environ. Health Perspect. 2012, 120, 1397-1403. [CrossRef]

19. James-Todd, T.; Stahlhut, R.; Meeker, J.D.; Powell, S.-G.; Hauser, R.; Huang, T.; Rich-Edwards, J. Urinary Phthalate Metabolite Concentrations and Diabetes among Women in the National Health and Nutrition Examination Survey (NHANES) $2001-2008$. Environ. Health Perspect. 2012, 120, 1307-1313. [CrossRef]

20. Yaghjyan, L.; Sites, S.; Ruan, Y.; Chang, S.-H. Associations of Urinary Phthalates with Body Mass Index, Waist Circumference and Serum Lipids among Females: National Health and Nutrition Examination Survey 1999-2004. Int. J. Obes. 2015, 39, 994-1000. [CrossRef]

21. López-Carrillo, L.; Hernández-Ramírez, R.U.; Calafat, A.M.; Torres-Sánchez, L.; Galván-Portillo, M.; Needham, L.L.; Ruiz-Ramos, R.; Cebrián, M.E. Exposure to Phthalates and Breast Cancer Risk in Northern Mexico. Environ. Health Perspect. 2010, 118, 539-544. [CrossRef]

22. Hoppin, J.A.; Jaramillo, R.; London, S.J.; Bertelsen, R.J.; Salo, P.M.; Sandler, D.P.; Zeldin, D.C. Phthalate Exposure and Allergy in the U.S. Population: Results from NHANES 2005-2006. Environ. Health Perspect. 2013, 121, 1129-1134. [CrossRef] [PubMed]

23. Xu, X.; Yang, Y.; Wang, R.; Wang, Y.; Ruan, Q.; Lu, Y. Perinatal Exposure to Di-(2-Ethylhexyl) Phthalate Affects Anxiety- and Depression-like Behaviors in Mice. Chemosphere 2015, 124, 22-31. [CrossRef] [PubMed]

24. Barakat, R.; Lin, P.-C.; Park, C.J.; Best-Popescu, C.; Bakry, H.H.; Abosalem, M.E.; Abdelaleem, N.M.; Flaws, J.A.; Ko, C. Prenatal Exposure to DEHP Induces Neuronal Degeneration and Neurobehavioral Abnormalities in Adult Male Mice. Toxicol. Sci. 2018, 164, 439-452. [CrossRef] [PubMed]

25. Hao, C. Perinatal Exposure to Diethyl-Hexyl-Phthalate Induces Obesity in Mice. Front. Biosci. 2013, E5, 725-733. [CrossRef]

26. Niermann, S.; Rattan, S.; Brehm, E.; Flaws, J.A. Prenatal Exposure to Di-(2-Ethylhexyl) Phthalate (DEHP) Affects Reproductive Outcomes in Female Mice. Reprod. Toxicol. 2015, 53, 23-32. [CrossRef]

27. Chen, S.-Q.; Chen, J.-N.; Cai, X.-H.; Chen, G.-R.; Gao, Y.; Ge, R.-S.; Wu, H.-S.; Lin, Z.-L.; Lin, J. Perinatal Exposure to Di-(2Ethylhexyl) Phthalate Leads to Restricted Growth and Delayed Lung Maturation in Newborn Rats. J. Perinat. Med. 2010, 38. [CrossRef] [PubMed]

28. Love, D.R.; Pichler, F.B.; Dodd, A.; Copp, B.R.; Greenwood, D.R. Technology for high-throughput screens: The present and future using zebrafish. Curr. Opin. Biotechnol. 2004, 15, 564-571. [CrossRef]

29. Sarvaiya, V.N.; Sadariya, K.A.; Rana, M.P.; Thaker, A.M. Zebrafish as model organism for drug discovery and toxicity testing: A review. Vet. Med. Sci. 2014, 2, 31-38.

30. Dooley, K. Zebrafish: A Model System for the Study of Human Disease. Curr. Opin. Genet. Dev. 2000, 10, 252-256. [CrossRef]

31. Segner, H. Zebrafish (Danio Rerio) as a Model Organism for Investigating Endocrine Disruption. Comp. Biochem. Physiol. C Toxicol. 2009, 149, 187-195. [CrossRef] [PubMed]

32. Yu, K.; Li, G.; Feng, W.; Liu, L.; Zhang, J.; Wu, W.; Xu, L.; Yan, Y. Chlorpyrifos is Estrogenic and Alters Embryonic Hatching, Cell Proliferation and Apoptosis in Zebrafish. Chem. Biol. Interact. 2015, 239, 26-33. [CrossRef]

33. Mu, X.; Huang, Y.; Li, X.; Lei, Y.; Teng, M.; Li, X.; Wang, C.; Li, Y. Developmental Effects and Estrogenicity of Bisphenol A Alternatives in a Zebrafish Embryo Model. Environ. Sci. Technol. 2018, 52, 3222-3231. [CrossRef] [PubMed]

34. Moreman, J.; Lee, O.; Trznadel, M.; David, A.; Kudoh, T.; Tyler, C.R. Acute Toxicity, Teratogenic, and Estrogenic Effects of Bisphenol A and Its Alternative Replacements Bisphenol S, Bisphenol F, and Bisphenol AF in Zebrafish Embryo-Larvae. Environ. Sci. Technol. 2017, 51, 12796-12805. [CrossRef]

35. Kimmel, C.B.; Ballard, W.W.; Kimmel, S.R.; Ullmann, B.; Schilling, T.F. Stages of Embryonic Development of the Zebrafish. Dev. Dyn. 1995, 203, 253-310. [CrossRef]

36. Nagel, R. DarT: The Embryo Test with the Zebrafish Danio Rerio-A General Model in Ecotoxicology and Toxicology. Altex 2002, 19 (Suppl 1/02), 38-48.

37. Pu, S.-Y.; Hamid, N.; Ren, Y.-W.; Pei, D.-S. Effects of Phthalate Acid Esters on Zebrafish Larvae: Development and Skeletal Morphogenesis. Chemosphere 2020, 246, 125808. [CrossRef] [PubMed]

38. Hamid, N.; Junaid, M.; Manzoor, R.; Jia, P.-P.; Pei, D.-S. Prioritizing Phthalate Esters (PAEs) Using Experimental in Vitro/Vivo Toxicity Assays and Computational in Silico Approaches. J. Hazard. Mater. 2020, 398, 122851. [CrossRef]

39. Muhammad, S.; Zhang, Z.; Pavase, T.R.; Guo, H. Long-Term Exposure of Two Plasticizers Di (2-Ethylhexyl) Phthalate (DEHP) and Acetyl Tributyl Citrate (ATBC): Toxic Effects on Gonadal Development and Reproduction of Zebrafish ("Danio Rerio"). Indian J. Mar. Sci. 2018, 47, 9. 
40. Ustundag, U.V.; Unal, I.; Ates, P.S.; Alturfan, A.A.; Yigitbasi, T.; Emekli Alturfan, E. Oxidant-Antioxidant Status and c-Myc Expression in BPA and DEHP-Exposed Zebrafish Embryos. Eur. J. Biol. 2017, 76, 26-30. [CrossRef]

41. Boran, H.; Terzi, S. Bis(2-Ethylhexyl) Phthalate Induces DNA Strand Breaks and Gene Expression Alterations in Larval Zebrafish Danio Rerio. Toxicol. Ind. Health 2019, 35, 520-529. [CrossRef] [PubMed]

42. Lu, C.; Luo, J.; Liu, Y.; Yang, X. The Oxidative Stress Responses Caused by Phthalate Acid Esters Increases MRNA Abundance of Base Excision Repair (BER) Genes in Vivo and in Vitro. Ecotoxicol. Environ. Saf. 2021, 208, 111525. [CrossRef]

43. McCollum, C.W.; Ducharme, N.A.; Bondesson, M.; Gustafsson, J.-A. Developmental Toxicity Screening in Zebrafish. Birth Defects Res. C Embryo Today 2011, 93, 67-114. [CrossRef]

44. Üstündă̆, Ü.V.; Ünal, İ.; Ateş, P.S.; Alturfan, A.A.; Yiğitbaşı, T. Bisphenol A and Di(2-Ethylhexyl) Phthalate Exert Divergent Effects on Apoptosis and the Wnt/ $\beta$-Catenin Pathway in Zebrafish Embryos: A Possible Mechanism of Endocrine Disrupting Chemical Action. Toxicol. Ind. Health 2017, 33, 901-910. [CrossRef]

45. Kinch, C.D.; Kurrasch, D.M.; Habibi, H.R. Adverse Morphological Development in Embryonic Zebrafish Exposed to Environmental Concentrations of Contaminants Individually and in Mixture. Aquat. Toxicol. 2016, 175, 286-298. [CrossRef]

46. Tran, C.M.; Do, T.N.; Kim, K.-T. Comparative Analysis of Neurotoxicity of Six Phthalates in Zebrafish Embryos. Toxics 2021, 9, 5. [CrossRef]

47. Lee, H.; Lee, J.; Choi, K.; Kim, K.-T. Comparative Analysis of Endocrine Disrupting Effects of Major Phthalates in Employed Two Cell Lines (MVLN and H295R) and Embryonic Zebrafish Assay. Environ. Res. 2019, 172, 319-325. [CrossRef]

48. Mu, X.; Huang, Y.; Li, J.; Yang, K.; Yang, W.; Shen, G.; Li, X.; Lei, Y.; Pang, S.; Wang, C. New Insights into the Mechanism of Phthalate-Induced Developmental Effects. Environ. Pollut. 2018, 241, 674-683. [CrossRef] [PubMed]

49. Park, C.-B.; Kim, G.-E.; Kim, Y.J.; On, J.; Park, C.-G.; Kwon, Y.-S.; Pyo, H.; Yeom, D.-H.; Cho, S.-H. Reproductive Dysfunction Linked to Alteration of Endocrine Activities in Zebrafish Exposed to Mono-(2-Ethylhexyl) Phthalate (MEHP). Environ. Pollut. 2020, 265, 114362. [CrossRef]

50. Kamstra, J.H.; Sales, L.B.; Aleström, P.; Legler, J. Differential DNA Methylation at Conserved Non-Genic Elements and Evidence for Transgenerational Inheritance Following Developmental Exposure to Mono(2-Ethylhexyl) Phthalate and 5-Azacytidine in Zebrafish. Epigenetics Chromatin 2017, 10, 20. [CrossRef] [PubMed]

51. Sant, K.E.; Moreau, H.M.; Williams, L.M.; Jocobs, H.M.; Bowsher, A.M.; Boisvert, J.D.; Smolowitz, R.M.; Pantazis, J.; Annunziato, K.; Nguyen, M.; et al. Embryonic Exposures to Mono-2-Ethylhexyl Phthalate Induce Larval Steatosis in Zebrafish Independent of Nrf2a Signaling.Pdf. J. Dev. Orig. Health Dis. 2020, 12, 132-140. [CrossRef]

52. Mu, X.; Chen, X.; Liu, J.; Yuan, L.; Wang, D.; Qian, L.; Qian, Y.; Shen, G.; Huang, Y.; Li, X. A Multi-Omics Approach Reveals Molecular Mechanisms by Which Phthalates Induce Cardiac Defects in Zebrafish (Danio Rerio). Environ. Pollut. 2020, 265, 113876. [CrossRef] [PubMed]

53. Qian, L.; Liu, J.; Lin, Z.; Chen, X.; Yuan, L.; Shen, G.; Yang, W.; Wang, D.; Huang, Y.; Pang, S. Evaluation of the Spinal Effects of Phthalates in a Zebrafish Embryo Assay. Chemosphere 2020, 249, 126144. [CrossRef]

54. Karczewski, K.J.; Snyder, M.P. Integrative Omics for Health and Disease. Nat. Rev. Genet. 2018, 19, 299-310. [CrossRef]

55. Junaid, M.; Jia, P.-P.; Tang, Y.-M.; Xiong, W.-X.; Huang, H.-Y.; Strauss, P.R.; Li, W.-G.; Pei, D.-S. Mechanistic Toxicity of DEHP at Environmentally Relevant Concentrations (ERCs) and Ecological Risk Assessment in the Three Gorges Reservoir Area, China. Environ. Pollut. 2018, 242, 1939-1949. [CrossRef]

56. Scholz, S.; Fischer, S.; Gündel, U.; Küster, E.; Luckenbach, T.; Voelker, D. The Zebrafish Embryo Model in Environmental Risk Assessment-Applications beyond Acute Toxicity Testing. Environ. Sci. Pollut. Res. 2008, 15, 394-404. [CrossRef]

57. Caldwell, J.C. DEHP: Genotoxicity and potential carcinogenic mechanisms-A review. Mutat. Res. 2012, 751, 82-157. [CrossRef]

58. Simon, H.-U.; Haj-Yehia, A.; Levi-Schaffer, F. Role of Reactive Oxygen Species (ROS) in apoptosis induction. Apoptosis 2000, 5, 415-418. [CrossRef] [PubMed]

59. Jia, P.-P.; Ma, Y.-B.; Lu, C.-J.; Mirza, Z.; Zhang, W.; Jia, Y.-F.; Li, W.-G.; Pei, D.-S. The Effects of Disturbance on HypothalamusPituitary-Thyroid (HPT) Axis in Zebrafish Larvae after Exposure to DEHP. PLoS ONE 2016, 11, e0155762. [CrossRef]

60. An, Y.; Lee, H.; Kim, K. Developmental Toxicity and Endocrine Disruption Effect of 6 Phthalates in Zebrafish Embryos. In Proceedings of the Annual Conference of Japan Society of Material Cycles and Waste Management The 29th Annual Conference of Japan Society of Material Cycles and Waste Management (p. 621), Nagoya, Japan, 12-14 September 2018.

61. He, J.-H.; Gao, J.-M.; Huang, C.-J.; Li, C.-Q. Zebrafish Models for Assessing Developmental and Reproductive Toxicity. Neurotoxicol. Teratol. 2014, 42, 35-42. [CrossRef]

62. Zhai, W.; Huang, Z.; Chen, L.; Feng, C.; Li, B.; Li, T. Thyroid Endocrine Disruption in Zebrafish Larvae after Exposure to Mono-(2-Ethylhexyl) Phthalate (MEHP). PLoS ONE 2014, 9, e92465. [CrossRef] [PubMed]

63. Rastogi, A.; Clark, C.W.; Conlin, S.M.; Brown, S.E.; Timme-Laragy, A.R. Mapping Glutathione Utilization in the Developing Zebrafish (Danio Rerio) Embryo. Redox Biol. 2019, 26, 101235. [CrossRef]

64. Jacobs, H.M.; Sant, K.E.; Basnet, A.; Williams, L.M.; Moss, J.B.; Timme-Laragy, A.R. Embryonic Exposure to Mono(2-Ethylhexyl) Phthalate (MEHP) Disrupts Pancreatic Organogenesis in Zebrafish (Danio Rerio). Chemosphere 2018, 195, 498-507. [CrossRef]

65. Sant, K.; Jacobs, H.; Xu, J.; Borofski, K.; Moss, L.; Moss, J.; Timme-Laragy, A. Assessment of Toxicological Perturbations and Variants of Pancreatic Islet Development in the Zebrafish Model. Toxics 2016, 4, 20. [CrossRef] [PubMed]

66. Pei, D.; Xin, G.-Y.; Junaid, M.; Wang, Y.; Ma, Y.-B. DEHP Chronic Exposure Disturbs the Gut Microbial Community and Metabolic Homeostasis: Gender-Based Differences in Zebrafish. Res. Sq. 2020, Preprint. [CrossRef] 
67. Padilla, S.; Corum, D.; Padnos, B.; Hunter, D.L.; Beam, A.; Houck, K.A.; Sipes, N.; Kleinstreuer, N.; Knudsen, T.; Dix, D.J. Zebrafish developmental screening of the ToxCast ${ }^{\mathrm{TM}}$ Phase I chemical library. Reprod. Toxicol. 2012, 33, 174-187. [CrossRef]

68. Dodd, A.; Curtis, P.M.; Williams, L.C.; Love, D.R. Zebrafish: Bridging the gap between development and disease. Hum. Mol. Genet. 2000, 9, 2443-2449. [CrossRef] [PubMed]

69. Xu, C.; Zon, L.I. The zebrafish as a model for human disease. In Fish Physiology; Perry, S.F., Ekker, M., Farrel, A.P., Brauner, C.J., Eds.; Academic Press: Burlington, MA, USA, 2010.

70. Tao, T.; Peng, J. Liver development in zebrafish. J. Genet. Genom. 2009, 36, 325-334. [CrossRef]

71. Blanton, M.L.; Specker, J.L. The hypothalamic-pituitary-thyroid (HPT) axis in fish and its role in fish development and reproduction. Crit. Rev. Toxicol. 2007, 37, 97-115. [CrossRef] [PubMed] 